\title{
Yazıcızâde Kardeşlerin Müntehâ Adlı Eserlerinin Tavsîfi Meselesi*
}

\section{The Problem of Describing the Books Called Munteha by the Yazidjizade Brothers}

\author{
Mehmet Bilâl Yamak $^{1}$ (), Tuba Bozbey² (1)
}

*Bu makale, Dr. Mehmet Bilal Yamak tarafindan İstanbul Üniversitesi Sosyal Bilimler Enstitüsü Temek İslâm Bilimleri Temel İslam Bilimleri Anabilim Dalı bünyesinde tamamlanan "Yazıcızâde Kardeşlerin Tasavvufí Görüşleri ve Osmanlı́ya Tesirleri" başlıklı tezden üretilmiştir; lâkin EK-2'de yer alan Ahmed-i Bîcân'ın 1465 tarihli Müntehâ adlı eserinde yer alan Yâsîn Sûresi tefsîri, Tuba Bozbey tarafından Osmanlı Türkçesinden Latinize edilmiştir. Söz konusu eserin tamamı Dr. Abdullah Uğur ve Dr. Mehmet Bilal Yamak tarafından neşre hazırlanmaktadır

${ }^{1}$ Sorumlu yazar/Corresponding author: Mehmet Bilal Yamak (Dr.),

Kırklareli Üniversitesi Ilahiyat Fakültesi Temel İslam Bilimleri Bölümü, Tasavvuf Anabilim Dalı, Kırklareli, Türkiye

E-posta: bilalyamak@gmail.com

ORCID: 0000-0002-7836-1792

${ }^{2}$ Kırklareli Üniversitesi Ilahiyat Fakültesi Lisans Öğrencisi, Kırklareli, Türkiye

ORCID: 0000-0001-6602-6586

\section{Başvuru/Submitted: 18.07.202}

Revizyon Talebi/Revision Requested: 08.08.2021

Son Revizyon/Last Revision Received: 02.09.2021

Kabul/Accepted: 22.09 .2021

Atıf/Citation: Yamak, Mehmet Bilâl \& Bozbey Tuba. Yazıcızâde Kardeşlerin Müntehâ Adlı Eserlerinin Tavsîfi Meselesi. İslam Tetkikleri Dergisi-Journal of Islamic Review. Islam Tetkikleri Dergisi-Journal of Islamic Review 11/2,

(Eylül 2021): 639-674

https://doi.org/10.26650/iuitd.2021.972867

\section{ÖZ}

Yazıcızâde Muhammed Efendi (ö. 855/1451) ve kardeşi Ahmed-i Bîcân (ö. 870/1466'dan sonra), Osmanlı tasavvuf târihinin temsîl gücü yüksek iki ismidir. Yazıcızâde Kardeşlerin eserleri, yüzyıllarca Osmanlı coğrafyasında ve bu coğrafyanın dışında okunmuş, üzerlerine şerhler yazılmış hatta Türkçenin haricindeki dillere de tercüme edilmiştir. Aynı zamanda $\mathrm{Hacı}$ Bayrâm-ı Velî́nin de derviş ve halîfeleri olan Yazıcızâde Kardeşlerin eserleri arasında, özellikle Muhammed Efendi'nin manzûm Muhammediyye, Ahmed-i Bîcân'ın ise mensûr Envâru'l-âşıkîn adlı eserleri; Osmanlı ulemâsı, sûfî çevreler ve halk tarafından en çok okunan, okutturulan kitaplar arasında addedilmektedir. Ayrıca; Muhammed Efendi'nin bir, Ahmed-i Bîcân'ın ise iki adet Fusûsu'l-hikem şerhinin târih ve nüsha ayrılıkları üzerinde bu çalışmaya kadar yeterince durulmamıştır. Bu eserler göz önünde bulundurulmadan Yazıcızâde Kardeşlerin tasavvufî görüşlerinin seyrini, üslûbunu ve bu görüşlerin uzun müddet Osmanlı çevrelerinde revaç bulmalarının sebebini anlamaya çalışmak ise zor olacaktır. Yazıcızâde Muhammed Efendi tarafından el-Müntehâ ale'l-Fusûs adıyla Arapça olarak yazılan Fusûsu'l-hikem şerhi kardeşi Ahmed-i Bîcân tarafından 857/1453 yılında Kitâbü'l-Müntehâ ale'lFusûs adıyla Türkçeye tevsîan tercüme edilmiş daha sonra 870/1465 yılında yine Ahmed-i Bîcân tarafından aynı adla bir eser daha kaleme alınmıştır. Bahsi geçen son iki eser Anadolu coğrafyasında Türkçe yazılmış ilk Fusûsu'lhikem şerhleri olma vasfını hâizdir. Ne var ki bu eserlerden bahseden bazı kaynaklar, söz konusu eserlerin Müeyyedüddîn-i Cendî́nin Fusûsu'lhikem şerhi üzerine yazılmış birer ta'likât olduğunu ifâde etmektedirler. Bu makâlede öncelikle bu hüküm tashih edilerek hükmün târihî seyri ve bu hükme sebep olan âmiller açığa çıkartılmaya çalışılacaktır. Akabinde; Yazıcızâde Kardeşlerin mevzubahis eserleri tavsîf edilecektir. Ahmed-i Bîcân'ın ikinci Fusûsu'l-Hikem şerhinin bir diğer özelliği de içerisinde müstakil sûre meâl ve tefsirlerini ihtivâ etmesidir. Tasavvuf tarihi, bâ-husûs Osmanlı tasavvuf, tefsîr ve Türk edebiyâtı tarihi açısından son derece önemli olan bu eserden de bir bölüm ilk kez bu makalede neşredilecektir.

Anahtar Kelimeler: Yazıcızâde Muhammed Efendi, Ahmed-i Bîcân, Yazıcızâde Kardeşler, İbn Arabî, Fusûsu'I-hikem, Osmanlı Tasavvufu, Müntehâ 


\begin{abstract}
Yazidjioghlu Muhammed Efendi (d. 855/1451) and Ahmad Bidjan (d. 870/ after 1466) are two representative names in Ottoman Sufism history. Their written works were read and commented on literally and even translated into other languages both in and out of the Ottoman Empire. The Yazidjioghlu brothers, at the same time, were the disciples and successors of Hadji Bayram Velî. The brothers wrote many books; however, Muhammed Efendi's verse Muhammadiyyah and Ahmad Bidjan's prose Anwâr al-Âshiqîn were accepted as the two books that were mostly read by the scholars, follewers of sufism and the wider public. Muhammed Efendi wrote a commentary on the Fusus al-Hikam of Ibn Arabi whereas Ahmad Bidjan wrote two but the differences between these books were not specified thoroughly. Without these studies, it would be hard to follow the course of Sufistic views of the Yazidjioghlu brothers and understand their style and comprehend the reasons for their influence on the Ottoman Empire for such a long time. Yazidjizade Muhammed Efendi wrote a commentary on Fusus al-Hikam entitled al-Muntehâ ala al-Fusus, which was translated into Turkish by his brother, Ahmad Bidjan, with the title Kitab alMunteha ala al-Fusus in 1453; in addition, Bidjan wrote another book with the same title in 1465 . These two books have the significance of being the first Turkish commentary on Ibn Arabi's famous book published in Anatolia. However, while discussing these books, some sources have regarded them as a taliqat/annotation of the work of Cendi. In this study, this judgment will be corrected, and the reasoning will be explicated by describing the Yazidjizade brothers' aforementioned works. Another distinctive feature of Ahmad Bidjan's second commentary on Fusûs al-Hikam is that it contains full commentaries and meanings of some verses of the Qur'an. An excerpt from this work that is of the utmost importance to the history of Sufism, especially to the Ottoman period of it, and to the histories of tafseer and Turkish literature will be published here for the first time.
\end{abstract}

Keywords: Yazıdjizade Muhammed Efendi, Yazıdjizade Brothers, Ahmad Bidjan, Ibn al-Arabi, Fusus al-Hikam, Ottoman Sufism, Munteha

\title{
EXTENDED ABSTRACT
}

Yazidjioghlu Muhammed Efendi (d. 855/1451) and Ahmad Bidjan (d. 870/ after 1466) are two representative names in Ottoman Sufism history. Their written works were read and commented on literally and even translated into other languages both in and outside the Ottoman land. The Yazidjioghlu brothers, at the same time, were the disciples and successors of Hadji Bayram Velî. The brothers wrote many books; however, Muhammed Efendi's verse Muhammadiyyah and Ahmad Bidjan's prose Anwâr al-Âshiqîn were accepted as the two books that were mostly read by the scholars, Sufi environments, and the wider public. For instance; Muhammediyye is the verse book of Muhammed Efendi, which had a profound impact on Ottoman Sufism, and he gained fame with this work. The work was famous not only in Anatolian circles; starting in the sixteenth century, it gained a great reputation in the Crimea among Kazan Turks and Bashkirs. Anwâr al-Âshiqîn, on the contrary, had the quality of being a popular book that was recited as a daily prayer, seen as one of the five books that were loved and read, and even memorized in every part of Ottoman society. It was translated into Hungarian in 1624 by the translator and clerk of Erdel Ruler Gábor Bethlen. The brothers continued the scientific tradition they inherited from their father, Yazidji Salih, with a systematic education. Classical and modern sources do not give detailed information about their training. The Yazidjioghlu brothers, who have a good command of the sciences of tafsir, hadith, fiqh, theology, and philosophy within the framework of the sources they use in their works and the views they prefer, attracted attention with the annotations in which they followed the heritage of Ibn al-Arabi and Konevi. Furthermore, these preferences determined their other scientific 
preferences. Although both of them are the teachers of their own educator; the brothers prefer Sayyid Shareef al-Jurcani over Teftazani because of his affinity with Sufism, and they do not refrain from criticizing Teftazani harshly. The Yazidjioghlu brothers are the disciples and successors of Hadji Bayram Veli. They are extremely respectful to him; however, they do not include the practical applications of the Bayrami Order in their works. Within the framework of the works they wrote, it can be said that they are closer to Ibn al-Arabi's manner than to the Bayrami Order. Despite this closeness, while being extremely respectful to the spiritual personality of Ibn al-Arabi, the approach they brought to the controversial issues of the relevant thought, such as the faith of the Pharaoh and the eternity of hell, differs from the tradition. They certainly do not accuse Ibn al-Arabi of some of the controversial issues he has raised because, according to them, Ibn al-Arabi is "innocent" and "excused". As a result of this understanding, the other interpretive approaches of the Yazidjioghlu brothers that can be handled in a minor and secondary way are to discuss the issues to be criticized in Fusus al-hikam to the judgement of the Quran, hadiths, and other “outer" sciences. Thus, by not failing to respect Ibn al-Arabi, they become the bearers of the thought of wahdat al-wujud. Simultaneously, they interpret the points that can be misunderstood by "others" with their "Sufi/scholar" identities. Muhammed Efendi wrote a commentary on the Fusus al-Hikam of Ibn Arabi whereas Ahmad Bidjan wrote two. However, the differences between these books were not specified thoroughly until that work. Without these studies, it would be hard to follow the course of Sufistic views of the Yazidjioghlu brothers and understand their style and comprehend the reasons for their influence on the Ottoman lands for such a long time. Yazidjizade Muhammed Efendi wrote a commentary on Fusus al-Hikam entitled al-Muntehâ ala al-Fusus and it was translated into Turkish by his brother, Ahmad Bidjan, titled Kitab al-Munteha ala al-Fusus in 1453; additionally, Bidjan wrote another book with the same title in 1465 . These two books have the significance of being the first Turkish commentary on Ibn Arabi's famous book published in Anatolia. However, while discussing these books, some sources have regarded them as a taliqat/annotation of the work of Cendi. In this study, this judgment will be corrected, and the reasoning will be explicated by describing the Yazidjizade Brothers' aforementioned works. Another distinctive feature of Ahmad Bidjan's second commentary on Fusûs al-Hikam is that it contains full commentaries and the meanings of some verses of the Qur'an. Ahmad Bidjan performed his tafseer practice within the framework of a definite method. His interpretation of the Qur'an regards a degree of understanding. He interprets the verses with the approaches of "tashree," "tahkeek," and “ta'weel." In particular, Ahmad Bidjan's Müntehâ II is important with its tafseer of eighteen independent surahs. An excerpt (Surah Yasin) from this work that is of the utmost importance to the history of Sufism, especially to the Ottoman period of it and to the histories of tafseer and Turkish literature will be published here for the first time. The reason why Surah Yasin was chosen from the eighteen surahs that took place in the book can be expressed as follows: Surah Yasin was described as the "heart of the Qur'an" by the Prophet (pbuh), and that is why this surah was interpreted independently in Ottoman tafseer and Sufism circles many times. After this publication, related comments can be compared with those of Ahmad Bidjan. Furthermore, this study will provide data in terms of the religious language of the century. 


\section{Giriş}

XV. yüzyılda Gelibolu'da yaşamış olan iki sûfî-müellif olan Yazıcızâde Muhammed Efendi ve kardeşi Ahmed-i Bîcân; klasik çağ Osmanlı'sının kalemiyye sınıfı mensuplarından babaları Yazıcı Sâlih tarafından ilmiyye, Hacı Bayrâm-1 Velî (ö. 833/1430) tarafından da sûfiyye mesleklerine dâhil edilmişlerdir. Yazıcızâde kardeşler, Osmanlı telif/tercüme literatüründe farklı ve dikkate değer bir usûl tâkip etmişlerdir. Şöyle ki Yazıcızâde Muhammed Efendi Megāarribü'zzamân li-g்urûbi'l-eşyâ' fi'l- 'ayn ve'l- 'lyân adlı eserini mensûr olarak kaleme almış, aynı eseri kardeşi Ahmed-i Bîcân Envâru'l-âşııîn adı ile yine mensûr olarak Türkçeye tercüme ederken; Muhammed Efendi, kendi yazdığg Arapça eseri Muhammediyye adı ile fakat nazmen tercüme etmiştir. Bu iki eserin muhtevâ ve şekil özellikleri açısından temâyüzleri bir kenara, Osmanlı kültüründe edindikleri yer ve geniş tesir sahaları da önemlidir. Lâkin tasavvuf ve edebiyat tarihlerinde bu iki esere çokça dikkat çekilirken bizce müelliflerin orijinal taraflarını teşkil eden Fusûsu'l-hikem şerhleri ihmâl edilmiştir. Şöyle ki; modern dönem çalışmalarında bu eserlerin muhteva ve keyfiyetleri dahi tam olarak tespit edilememiş ve aşağıda ele alınacak olan yanlış bir düzlemde incelenmiştir. Hâlbuki söz konusu eserler Osmanlı düşünce dünyasını şekillendiren Ekberî geleneğin Osmanlı coğrafyasına serpilen tohumları mesabesindedir. Çünkü iki müellifin Fusûsu'l-hikem şerhlerinde serdettikleri görüşler; Envâru'l-âşıkîn ve Muhammediyye aracılığ ile halk muhayyilesine intikâl etmiştir. Yazıcızâde kardeşlerin eserlerinin tavsifi özellikle Fusûsu'l-hikem şerhlerinin doğru bir şekilde tanıtılması ehemmiyyet arz etmektedir.

Aynı konu üzerinde kaleme alınan bir eseri ya da mahsus bir kitap üzerine yazılan bir şerhi orijinal kılan husus, kendinden evvel yazılan fikirlere verdiği nizâm ve hareket olmalıdır. Keşfü'z-zünûn müellifine göre ise bir eser, ancak yedi sebep neticesinde kaleme alınır. Ona göre akıllı bir âlim bu yedi sebepten en az biri söz konusu değilse eser yazmamalıdır. Kâtib Çelebi'nin zikrettiği sebepler şöyle sıralanır:

"1- Daha önce hiç kaleme alınmamış bir mevzuyu yazmak.

2- Yazılan bir eserdeki eksiği tamamlamak.

3- Muğlak bir eseri şerh etmek.

4- Manasına halel getirmemek şartıyla uzun bir eseri ihtisâr etmek.

5- Dağınık olan malumatı bir araya getirmek.

6- Düzensiz olan malumatı tertip etmek.

7- Yazarın hatalarını düzeltmek."1

Kâtib Çelebi'nin bir eserin kaleme alınması için sebep olarak ortaya koyduğu şartların birinci, üçüncü ve nisbeten de yedinci maddeleri Yazıcızâde Kardeşlerin Fusûsu'l-hikem'i şerh etmelerinin sebepleri olarak belirlenebilir. Çünkü onlar; "Daha önce hiç kaleme alınmamış bir konuyu yazmışlardır.” İbn Arabî’yi ve eserini, aşağıda arz edilecek olan sebepler çerçevesinde "ma“zûr" ve "me’mûr" olarak görmüşler ve eserlerini bu ana temel üzerine binâ etmişlerdir. Bu kısa girişten sonra eserler hakkında bilgi vermeye geçilebilir.

1 Kâtib Çelebi, Keş̧ü'z-zünûn, nşr. Şerefettin Yaltkaya - Kilisli Rifat Bilge (Ankara: Türk Tarih Kurumu, 2014), $1 / 31$. 


\section{Yazıcızâde Muhammed Efendi'nin Müntehâ'sı}

Yazıcızâde Muhammed Efendi'nin, hicrî 853 senesinin Recep ayının evvelinde (Eylül 1449), Hz. Peygamber'i (s.a.v.) rüyasında gördükten sonra yazmaya başladığını ifâde ettiği ${ }^{2}$ ve Arapça olarak kaleme aldığı Müntehâ adlı eseri, Muhyiddîn-i Arabî'nin Fusûsu'l-hikem adlı eserinin şerhidir. "Müntehâ" kelimesinin anlamını Ahmed-i Bîcân şu şekilde aktarır: "Müntehâ dirler kim yirden bir nesne u'rûc ider ana vurur anda müntehî olur. Ve her nesne kim yukarudan aşaga nâzil olur anda tamâm nihâyet bulur anun-çün müntehâ dirler."’3 Yani "Müntehâ" kelimesi bir manâda seyr u sülûkun varacağı yer anlamına gelmektedir. Yazıcızâde Muhammed Efendi; Hicrî 853 senesinin Cemâziyelâhir ayının sonunda (Ağustos 1449) bittiği bilinen Muhammediyye'yi tamamlar tamamlamaz Müntehâ adlı eserini yazmaya başlamıştır. Gelibolulu Mustafâ Âlî (ö. 1008/1600) tarafından müellifin ilm-i zâhirdeki fazlına tanık olarak gösterilen ${ }^{4}$ eserin müellif hattı nüshası kayıptır. ${ }^{5}$ Klasik kaynaklar, eserin Fusûsu'lhikem üzerine bir şerh olduğu noktasında ittifâk etmiş olsalar da eser hakkında tafsîlî malûmat vermezler. ${ }^{6}$ Eserin İbn Arabî’nin görüşlerine farklı yorumlar getirmesine yönelik ortaya

2 Yazıcızâde Muhammed Efendi, Şerhu Fusûsu'l-Hikem (Müntehâ), nşr. İbrâhim el-Keyyâlî (Beyrut: Kitâb Nâşirûn, 2013), 61.

3 Abdullah Uğur, Yazıcıoğlu Ahmed Bîcân Efendi ve Envâru'l Âşıkin Adlı Eseri (İnceleme-Metin) (İstanbul: Marmara Üniversitesi, Türkiyat Araştırmaları Enstitüsü, Doktora Tezi/Ph.D. Dissertation, 2019), 453.; Bu eser basılmıştır: Harvard: Ottoman Studies Foundation, 2019.

4 Gelibolulu Mustafa Âli, Künhü'l-Ahbâr, nşr. Ali Çavuşoğlu (Ankara: Türk Tarih Kurumu, 2019), 167.

5 Ahmed Bâdî Efendi (ö. 1910), eserin bizzat müellif tarafindan ta 'lîk hattı ile yazılan bir nüshasının mevcudiyetinden bahseder. Bk. Ahmed Bâdî Efendi, Riyâz-ı Belde-i Edirne- 20.Yüzyıla Kadar Osmanlı Edirne’si, nşr. Niyazi Adıgüzel - Raşit Gündoğdu (Edirne: Trakya Üniversitesi Yayınları, 2014), 2155. Süleymâniye Kütüphanesi Pertev Paşa koleksiyonu 293 numaraya kayıtlı nüshanın ketebe kaydında Muhammed Efendi'nin ismi geçiyor olsa da; yazmanın yazı ve kağıt özellikleri bu nüshanın müellif hattı olması ihtimâlini zayıflatmaktadır. Eserin tespit edebildiğimiz diğer bazı nüshaları şunlardır: Süleymaniye Kütüphanesi Nuruosmâniye, nr. 2466. Halet Efendi, nr. 262. Pertev Paşa, nr. 293. Kütahya Zeytinoğlu İlçe Halk Kütüphânesi, nr. 43 Ze 1126. (Bu yazma, katalogda sehven Ahmed-i Bîcân'a nisbet edilmiştir). İBB Atatürk Kitaplığı, nr. OE Yz 249 (Bu yazma, katalogda sehven Ahmed-i Bîcân'a nisbet edilmiştir). Manisa Akhisar, Zeynelzâde, nr. 45 Ak Ze 497.; Son zikredilen nüsha neşredilmiştir: Yazıcızâde Muhammed Efendi, Şerhu Fusûsu'l-Hikem (Müntehâ), nşr. İbrâhim el-Keyyâlî (Beyrut: Kitâb Nâşirûn, 2013).

6 Kâtib Çelebi, Keş̧ü'z-zünûn, 2/1263. Taşköprülüzâde Ahmed Efendi, eş-Şekâi 'ku'n-Nu 'mâniyye fí Ulemâi-dDevleti 'l-Osmâniyye-Osmanl Alimleri (İstanbul: Türkiye Yazma Eserler Kurumu, 2019), 191. Gelibolulu Mustafa Âli, Künhü'l-Ahbâr, 167. Müstakîmzâde Süleymân Saadeddin Efendi, Tuhfe-i Hattâtîn, nşr. İbnülemin Mahmud Kemal İnal (Ankara: Türk Tarih Encümeni, 1928), 706. Ahmed Bâdî Efendi, Riyâz-ı Belde-i Edirne- 20.Yüzyıla Kadar Osmanl Edirne'si, nşr. Niyazi Adıgüzel - Raşit Gündoğdu (Edirne: Trakya Üniversitesi Yayınları, 2014), 3/2155. Bursalı Mehmed Tâhir, Osmanlı Müellifleri (İstanbul: Matbaa-i Âmire, 1333), 1/195. 
konulan mülâhazalar 1915-1925 arasında kaleme alınan bazı eserlerde görülmektedir. ${ }^{7}$ Eserin Müeyyedüddîn-i Cendî’nin (ö. 691/1292?) Şerhu Fusûsi'l-hikem isimli kitabına yazılan bir ta 'lîkât olduğu bilgisi doğru değildir. Şöyle ki; Yazıcıoğlu Mehmed Efendi ve Muhammediyye si başlıklı doktora tezini 1971 yılında tamamlayan Âmil Çelebioğlu, Cumhuriyet döneminde Yazıcızâde kardeşler hakkında en fazla çalışma yapan ilim adamıdır. Millî Ĕğitim Bakanlı̆̆ Íslam Ansiklopedisi için "Yazıcıŏlu" maddesini, Diyanet İslâm Ansiklopedisi için ise "Ahmed Bîcân” maddesini kaleme almıştır. Doktora tezinde Muhammed Efendi'nin Müntehâ'sı ile alâkalı tasvîrî bilgiler veren Çelebioğlu bize göre daha sonra kitabın ilmî tasvirlerine tesir edecek ve bundan sonra Müntehâ adlı eserin Cendî ile beraber zikredilmesine sebep olacak şu ifâdeyi kullanır: “(Müntehâ) Muhyiddîn-i Arabî’nin Fusûsu'l-hikem'inin güzel bir üslupla muhtasar bir şerhidir. Muhyiddîn-i Arabî’nin birçok şerhlerine Şeyh Müeyyedüddîn-i Cendî’nin şerhi kaynaklık etmiştir ki bu arada bizzat Yazıcıoğlu Mehmed de bunu kendi eserinde tasrîh eder." "Aynı müellif Diyanet İslam Ansiklopedisi için 1989 yılında "Ahmed Bîcân” maddesini yazar. Burada da Muhammed Efendi'nin Müntehâ'sı şu şekilde zikredilir: "Kısaca Müntehâ olarak tanınan bu eser (Ahmed-i Bîcân'ın Müntehâ's1), Muhyiddin İbnü'l-Arabî'nin Fusûsu'lhikem'inin Müeyyed Cendî şerhine, Yazıcıoğlu Mehmed'in Müntehâ adıyla yine Arapça olarak yazdığı şerhin Ahmed Bîcan tarafından yapılan Türkçe tercümesidir."”

Bu ifâdelere göre Müntehâ Cendî şerhine yazılan bir şerhtir. 1989 yılında yayımlanan bu maddenin ardından 1993 senesinde Diyanet İslam Ansiklopedisi'nde neşredilen "Cendî" maddesinde eser; "Hacı Bayrâm-1 Velî’nin halifelerinden Yazıcıŏlu Mehmed, Cendî’nin şerhine Müntehâ adlı bir şerh yazmış..." neşredilen "Fusûsu'l-hikem" maddesinde ise kitaptan şu şekilde bahsedilmiştir: "Yazıcıoğlu Mehmed'in bu şerh üzerine (Cendî Şerhi) Müntehâ 'ale'l-Fusûs adlı Arapça bir ta'likatı bulunmaktadır."11 Mukaddem kaynaklarda bulunmayan; lâkin muâsır kaynaklarda bolca yer

7 Bursalı Mehmed Tâhir Bey (ö. 1925) eserde geçen bazı görüşlerin Muhammed Efendi’nin irfânı ile mütenâsib olmadığını ifâde ederek, bu görüşlerin esere sonradan medsûs olabileceğini yahut eserin müellif tarafindan Hacı Bayrâm-1 Velî ile karşılaşmasından evvel kaleme alınmış olabileceğini ifâde eder. Halbûki eser müellifin son eseridir. İlgili görüş için bk. Bursalı Mehmed Tâhir, Osmanlı Müellifleri, 195. Osmanzâde Hüseyin Vassaf Efendi (ö. 1929) ise eser ile ilgili şu görüşleri ifâde eder: "Muhammed Efendi Hazretleri'nin (...) Muhyiddîn-i Arabî hazretlerinin Fusûs'u üzerine bir şerh yazdıkları menkûldür. Bunda Hz. Muhyiddîn’e bir çok i'tirâzâtta bulunduğu mervî ise de vâkıf-1 esrâr-1 tevhîd olan müşarünileyhin böyle bir halde bulunmayacağına kanaat etmek lâzım gelir. Fusûs'a mu'tariz olan, tabiî onu şerh etmeye kalkışmaz. Şerhden maksad, metni erbâb-1 ma'rifete kapalı olan cihetlerini açmaktır ve Hz. Müellifin eserini tamîm etmekten ibârettir. Tabiî itirazla tevfîk kabul etmez." Osmanzâde Hüseyin Vassâf, Sefinne-i Evliyâ, nşr. Mehmet Akkuş - Ali Y1lmaz (İstanbul: Kitabevi, 2011), 2/463. Vassâf Efendi’nin "menkûldür” ve "mervîdir" şeklindeki ifâdelerinden eseri görmediği anlaşılmaktadır.

8 Yazıcığlu Muhammed, Muhammediye, nşr. Âmil Çelebioğlu (İstanbul: Dergâh Yayınları, 2018), 171.

9 Âmil Çelebioğlu, “Ahmed Bîcan”, Türkiye Diyanet Vakfi İslam Ansiklopedisi (İstanbul: TDV Yayınları, 1989), $2 / 50$.

10 Süleyman Uludağ, "Cendî”, Türkiye Diyanet Vakfi İslam Ansiklopedisi (İstanbul: TDV Yayınları, 1993), 7/361.

11 Mahmud Erol Kılıç, "Fusûsul-Hikem”, Türkiye Diyanet Vakfi Íslam Ansiklopedisi (İstanbul: TDV Yayınları, 1996), $13 / 232$. 
bulan $^{12}$ ve Yazıcızâde Muhammed Efendi'nin eserini Cendî şerhine ta'lîkat ya da bazen de bu şerhe şerh olarak gösterilmesine kaynaklık eden metin, tespit edebildiğimiz kadarı ile Âmil Çelebioğlu'nun 1989 tarihinde yazmış olduğu "Ahmed Bîcân” maddesidir. Çelebioğlu, doktora tezinde Cendî şerhini mezkûr esere kaynak olarak göstermiş, daha sonra yazdığı maddede ta 'lîkât olarak tavsîf etmiştir. Kanaatimizce bu görüş yanlıştır. Çünkü Cendî ismi, Muhammed Efendi tarafından eserin yazılışına sebep olan vâkıât ile berâber sadece bir kere zikredilmektedir. Mevzubahis metnin tercümesi şu şekildedir: "Bana garip bir adam geldi. Elinde de bir kitap vardı. Kitabı okudum. Kitapta Celâleddîn Hocendî, Özcendî’den, O da Müeyyedü'l-Cendî' den, o dahi Şeyh hazretlerinin (İbn-i Arabî) bazı ashâbından rivâyet ettiler ki: ..."13 Metinden de anlaşılacağı üzere Muhammed Efendi’ye gelen bir şahsın elindeki kitapta, içinde Müeyyedüddîn-i Cendî’nin de yer aldığı bir rivayet silsilesinden gelen bir bilgi vardır. Eserde Cendî ismi bu yerin haricinde üç yerde daha geçmektedir. ${ }^{14}$

Gerek bu eserde gerek ise Ahmed-i Bîcân tarafindan yapılan tercümesinde Cendî’ye yapılan bir ta'lîkâttan bahsedilmez. Ayrıca kitaplar Cendî şerhi ile kıyas edildiğinde telif şekillerinin farklı olduğu anlaşılır. Cendî şerhi klasik manâda ana metnin her cümlesini izah eden bir üslûp kullanmaktadır. Muhammed Efendi bu üslûbu tercih etmez. Hatta Fusûsu'l-hikem'in tertip sırasında değişiklik yapar, metinden nisbeten daha az iktibasta bulunur. Kısacası bu eser ile Cendî’nin eseri arasında irtibat kurmamıza imkan tanıyacak yeterli veri bulunmamaktadır.

Yazıcızâde Muhammed Efendi, eserinin dîbâcesinde kitabın yazılış gâyesini şu şekilde anlatır:

“Bir gün rüyada kendimi Rasûlullâh’ın karşısında elimde bir kitapla otururken gördüm. Bana baktılar ve şöyle buyurdular: 'Bundan sonra senin tedrisinle ben meşgul olacağım.' Sabaha erişince kalbimin O’nun nuru ile münevver olduğunu gördüm. Rasûlullâh'ın nûru ile nurlanmış olan kalbim bana şöyle dedi: 'Fusûs, râsihlerin (manevî ilimlerde derinleşmiş olanların) kalpleri için büyük bir delildir fakat nâsihlerin (zâhir ulemâsının-vâizlerin) akılları için de büyük bir imtihandır. Çünkü Fusûs'ta şerîatlere muhâlif, mazaret ve bahane kaldırmaz ifâdeler vardır. Tertîbi, enbiyâ ve mürselîn tertibi üzerine değildir. (...)' Bir gün bana acâip bir adam geldi, elinde bir kitap vardı. Kitabı mütâlaa ettim. Kitapta Cendî’nin, İbn Arabî’nin bazı dostlarından, onların da İbn Arabî’ den rivâyet ettikleri bir ibâre vardı:

“İbnü’l Arabî dedi ki: ‘Ben bu eserimde Kitâb’a muhalif olan şeyleri neden açık açık yazdım bilir misin? Çünkü Rasûlullâh beni itikatlarını imtihana tâbii tutayım diye ümmetine bir fitne

12 Metinde geçen çalışmalardan başka diğer bazı örnekler için bk. Hanife Dönmez, Muhammediye'de İnsan-l Kamil Düşüncesi (İstanbul: İstanbul Üniversitesi, Sosyal Bilimler Enstitüsü, Doktora Tezi/Ph.D Dissertation, 2018), 75; Mehmet Fatih Özcan, Envârü'l-Âşıkîn ve Muhammediye'de Manevi Eğitim (Konya: Necmettin Erbakan Üniversitesi, Eğitim Bilimleri Enstitüsü, Yüksek Lisans Tezi, 2019), 25; Münüre Beyhan Ergiri, Muhammediye ve Envârü'l-Âşıkîn'de Hz. Ali, (İstanbul: Üsküdar Üniversitesi, Tasavvuf Araştırmaları Enstitüsü, 2020), 21.

13 Yazıcızâde Muhammed Efendi, Şerhu Fusûsu'l-Hikem (Müntehâ), 62.

14 Muhammed Efendi, Fusûsu'l-hikem 'i şerhederken önceki şerhlerden iktibaslarda bulunur. Cendî’nin zikredildiği yerler de bu minvaldedir ve herhangi bir ta'lîkât özelliği taşımamaktadır. Bk. Yazıcızâde Muhammed, Şerhu Fusûsu'l-Hikem (Müntehâ), 73, 91, 178. 
ve rahmet olarak gönderdi. Zaman dediğin şey bozulup gitti. Emniyetten eser yok. İlhâd ehli ile tevhîd ehlinin temyîz sebebiyim ben. Kim ki hakîkî mü'mindir şerîat caddesinden sapmaz. İlhâd ehli ise hidayetten şaşar, hevâsına uyar.'

Sordum: 'Böyle irşâd câiz midir?'

Buyurdular: 'Allâh'tır doğruyu bilen. Lâkin ben me'mûrum. Me'mûr dahi ma'zûrdur.'15

Bu iktibastan sonra Muhammed Efendi, Fusûsu'l-hikem' in içinde bulunan tehlikeli vartalara işaret ettiğini ve kitabın tehlikeli noktalarını, imtihân sebebi olan yerlerini göstermek için bu kitabı kaleme aldığını ifâde eder. Bu esâsa mebnî olarak da kitapta yer yer İbn-i Arabî’ye itiraz eder. Hûd Fass'ında kâfirlerin cehennemde ebedî kalmayacaklarına dâir ifâdelere karşı çıkmanın yanı sıra, Dâvud-i Kayserî (ö. 751/1350) ile mukadder suâl ve cevaplar vesilesi ile münâzarada bulunur. Bu ciheti de eseri diğer Fusûsu'l-hikem şerhlerinden ayıran mümeyyiz vasıflarındandır. Eserde Fusûsu'l-hikem'deki enbiyâ tertibi değiştirilmiştir. Lût ve Lokmân fassları ise şerh edilmemiştir. "Vücûd”, "adem”, "imkân”, "mâhiyyet” gibi konuların tasavvufî bir bakış açısıyla incelendiği on dört temhîd ile başlayan eser, Fusûsu'l-hikem'deki fassların şerhi ile devâm eder.

Ekberî şerh geleneğinin husûsî ile Sadruddîn-i Konevî (ö. 673/1274) tarafindan felsefi bir telif tarzına bürünmesinin tesirleri Müntehâ'da da göze çarpar. Eserin hemen başında ilm-i ilâhî'den bahsedilmesi ve ilm-i ilâhî'nin mevzûu, mebâdîi ve mesâilinin izahı ve ardından vücûd ile alâkalı kelâmî ve felsefî̀ meselelerin tasavvuf zaviyesinden değerlendirilmesi dikkate değer bir husustur. Kitabın sonunda 63 beyitlik müstezat şeklinde Arapça olarak nazmedilmiş bir Kaside-i Rabbâniyye vardır.

\section{Ahmed-i Bîcân’ın Müntehâ'ları}

Kaynaklarda genellikle, Yazıcızâde Muhammed Efendi'nin Arapça bir Fusûsu'l-hikem şerhi kaleme aldığı, kardeşi Ahmed-i Bîcân'ın da bu eseri Türkçeye tercüme ettiği ve bu tercüme esere de aslı ile aynı şekilde Müntehâ adını verdiği zikredilir. ${ }^{16}$ Âmil Çelebioğlu'nca eser, bazı nüshalara göre 857/1453, bazı nüshalara göre ise 870/1465 yılında Gelibolu'da tamamlanmıştır. ${ }^{17}$ Aynı adlı bu iki eserin dîbâce, muhtevâ ve hâtime kısımları incelendiğinde; adları aynı olsa dahi iki farklı eserin mevzubahis olduğu görülmektedir. Bu hususa ilk defa dikkat çeken ise Behced Gönül'dür (Behçet Necatigil). ${ }^{18}$ İki farklı tarihli nüshayı kıyaslayan

15 Yazıcızâde Muhammed Efendi, Şerhu Fusûsu'l-Hikem (Müntehâ), 61, 62.

16 Örnek için bk. Çelebioğlu, "Ahmed Bîcan”, 2/50. Âmil Çelebioğlu - Kemal Eraslan, "Yazıcı-oğlu”, İslam Ansiklopedisi (İstanbul: MEB, 1986), 13/366. İki farklı nüshanın tefrik edilmediği diğer bir çalışma için bk. Ahmed Bîcân, Müntehâ- fusûsu'l-hikem üzerine bir çalışma, nşr. Ayşe Beyazıt (İstanbul: İnsan Yayınları, 2011). Ayşe Beyazıt, Müntehâ I'i yayıma hazırlamıştır. (Bu çalışmada, Ahmed-i Bîcân'ın Müntehâ adlı eserlerinin 857/1453 tarihli olanından Müntehâ I; 870/1465 tarihli muahhar olanından ise Müntehâ II şeklinde bahsedilmektedir.) Ayşe Beyazıt, neşre hazırladığı metnin giriş kısmında Ahmed-i Bîcân'ın iki eserini tefrik etmemiş olsa da yayıma hazırladığı eser genel itibarı ile sorunsuzdur.

17 Çelebioğlu, "Ahmed Bîcan”, 2/50.

18 Ayrıntılı bilgi için bk. Behced Gönül, Yazıcı Selahattin ve Oğulları: Hayatları ve Eserleri, (İstanbul: İstanbul Üniversitesi, Edebiyat Fakültesi Lisans Tezi, 1938/1939 Dönemi). 
Gönül, eserlerin kısaca muhtevâ tahlîlini yaparak nüshaların aynı adı taşımasına rağmen farklı iki eser olduğu hükmüne varmış; lâkin muhtevâ farklarının üzerinde yeterince durmamıştır. Eserlerin aşağıdaki tavsîfleri de bizi aynı neticeye ulaştırmakla beraber yeni bazı bilgilere de ulaşmamıza vesile olacaktır.

\subsection{Müntehâ I}

Yazıcızâde Muhammed Efendi'nin küçük kardeşi Ahmed-i Bîcân, yukarıda da belirtildiği gibi ağabeyinin yazmış olduğu eseri tercüme etmiştir. Eserin başında "Ve ben duâcı dahi onu Türkîye döndürdüm." ${ }^{19}$ şeklinde bu tercüme faaliyetini kendisi de ifade etmektedir. Eserin tamamlanış tarihi ise bizzat kendisi tarafından verilmiştir: "Ve târih sekiz yüz elli yedi senede Sultan Muhammed bin Murâd Hân (halled-Allâhu devletehû) İstanbul'u feth edicek Cemâziye'lûlâ'nın yirminci gününde idi bu kitâb temâm oldu." ${ }^{20}$ Kitabın, bizzat kendisi tarafından abisinin eserinden Türkçeye aktarıldığını ifâde eden Ahmed-i Bîcân, kitabın hâtimesinde ise bu eseri bir rüya neticesinde "cem" "ettiğini ifade eder. O halde bu kitabı hangi te'lif sınıfına dâhil etmek gerekir? Bu eser bir tercüme midir, derleme midir? Bu sorunun cevabını vermeden evvel eski edebiyatımızdaki tercümenin manâsını ve muhtevâsını tespit etmek gerekir. Eski edebiyatımızda tercümeyi şu şekillerde görmekteyiz:

“a. Aslını bozmamak için kelime kelime yapılan çeviriler.

b. Kelime kelime olmamakla birlikte aslına uygun yapılan çeviriler.

c. Konusu aktarılarak yapılan çeviriler.

d. Genişleterek yapılan çeviriler."21

Bu tasnîften hareket ederek; Ahmed-i Bîcân tercümesinin kitabın giriş kısmı itibarı ile "Kelime kelime olmamakla birlikte aslına uygun çeviriler" maddesine, umûmî olarak ise "Konusu aktarılarak yapılan çeviriler" maddesine ve ayrıca "Genişleterek yapılan çeviriler" maddesine muvafik olduğu söylenebilir. Çünkü kaynak ve hedef metin arasında her ne kadar "ana fikir" itibarı ile bir yeknesaklık var ise de hedef metinde göze çarpar şekilde eklemeler bulunmaktadır. Metnin içerisine sirayet ettirilen ilâvelerin yanı sıra kaynak metinde olmayan bazı bölümler de hedef metne eklenmiştir. Bu bölümlerden başlıcaları; "Fasl fî Istılâhâtı'ssûfiyye"(Abdurrezzâk-1 Kâşânî'nin (ö. 736/1335) Istılâhâtü's-sûfiyye adlı eserinden iktibâs edilen tasavvufî̀ kavramlar bölümü), "Fasl fî Menâzili’s-sâirîn" (Abdullâh-1 Herevî’nin (ö. 401/1011) Menâzilü 's-sâirîn adlı eserinden iktibâs yapılan bölüm) ve "Fasl fî Tezkireti'l-Evliyâ" (Feridüddîn-i Attâr'ın (ö. 618/1221) Tezkiretü'l-evliyâ adlı eserindenden alıntı yapılan bölüm) şeklinde sıralanabilir. Kanaatimizce bu eseri orijinal kılan bölümler bunlardır. Abdurrezzâk-1 Kâşânî'nin Istılâhâtü's-sûfiyye adlı tasavvufî kavramlara ait eserinden tercüme edilen kısımda Kâşânî'nin eserine dercettiği 511 1stılâhtan 117'si Müntehâ I'e dâhil edilmiştir. Bu da eserin müktebes eserin \%22,9'una tekâbül etmektedir. Küllî olarak tercüme edilen kısım sadece

19 Ahmed Bîcân, Müntehâ- fusûsu'l-hikem üzerine bir çalışma, 101.

20 Ahmed Bîcân, Müntehâ- fusûsu'l-hikem üzerine bir çalışma, 499.

21 Agah Sırrı Levend, Türk Edebiyatı Tarihi, (İstanbul: Dergâh Yayınları, 2015), 80. 
"ba" harfinin altında sıralanan ıstılâhâttır. "Ayn" harfinde bulunan 127 1stılâhın ise sadece 7'si tercüme edilmiştir. Eserde 24 adet sûfî biyografisi ilâve ve çıkartma yapmak sûretiyle tercüme edilmiştir. Bu noktada dikkate şâyân diğer bir husus da söz konusu bölümün, Ahmed-i Bîcân'ın, kendisinin ve ağabeyinin şeyhi olan Hacı Bayrâm-1 Velî’nin (ö. 833/1430) silsilesini ihtivâ etmesidir. Eserde yer alan sûfîlerin adlarının seci‘li üslup şeklinde takdimi de bölüme edebî bir değer katmaktadır. ${ }^{22}$ Kitabın söz konusu hususiyetine şu misâller verilebilir: "Ol tâbiin kıblesi ve ol hem nefes-i Rahmânî, ol Süheyl-i Yemenî Üveys el-Karanî, ol fakîr-i 'ademî Habîb-i 'Acemî, ol Meryem-i sâniyye Râbia-i 'Adeviyye, ol perverde-i ekrem İbrâhim b. Edhem, ol deryâ-yı mevvâc Mansûr-i Hallâc vd."’23

Yukarıda, Yazıcızâde Muhammed Efendi'nin Müntehâ adlı eserinde Fusûsu'l-Hikem'deki enbiyâ tertibini değiştirdiği ifâde edilmişti. Ahmed-i Bîcân ise ağabeyinin tertibine sadık kalmakla beraber sebep göstermeksizin Lût, Lokman ve Hâlid fasslarını eserine dâhil etmemiştir.

\subsection{Müntehâ II}

Tamamlanma tarihi bizzat Ahmed-i Bîcân tarafından, eserin tetimme kısmında, hicrî 870 senesinin Muharrem (Ağustos/Eylül 1465) ayı olarak verilen Müntehâ $I I^{24}$ her ne kadar 857/1453 senesinde yazılmış olan eserle aynı adı taşısa da tertip ve muhtevâ olarak farklılık arz etmektedir. ${ }^{25}$ Müntehâ I' in dîbâcesinde yer alan, eserin Muhammed Efendi'nin Arapça kaleme aldığı kitabın tercümesi olduğu ifadesi bu kitapta yer almaz. Zamanının âlimlerinin zâhir ve bâtın ilimlerde birçok eserler yazdıklarını fakat bu kitapların Arapça olduğunu vurgulayan müellif; Arapça bilmeyenlerin de bahsedilen ilimlerden istifade etmesi için eserini Türkçe olarak kaleme aldığını ifade eder. Ahmed-i Bicân, âlemin evvelinden âhirine kadar ulemânın esrârı ve urefânın envârı nâmına ne varsa; teşri', tahkîk ve te'vîl üzerine bir araya getirdiğini ifade ederek kitabı te'lîf usûlünü izâh etmektedir. Eserde bulunan Fusûsu'l-hikem şerhi Müntehâ I'den ihtisâren yapılmıştır. Şerhte Âdem Fassı atlanmış, fass tertiplerinde küçük değişiklikler yapılmış; Firavun'un imanı, Cehennem azabının ebedi olmadığı gibi tartışmalı konulara girilmemiştir. Fassların içerisinde daha çok kısas-1 enbiyâya yer verilmiştir. Yazıcızâde Kardeşler; bir anlamda, bahsi geçen peygamberlerin bâtınî (dikey) hayatları ile zâhirî (yatay) hayatlarını beraberce okuyucuya sunmuşlardır. Tespit edilebildiği kadarıyla bu Fusûsu'l-hikem

22 Seci“ nesrin kâfiyeli olmasıdır. Tâhirü’l-Mevlevî, Edebiyat Lügatı, nşr. Mustafa Kirenci (İstanbul: Büyüyenay Yayınları, 2019), 171. "Seci'” ile ilgi daha ayrıntılı bilgi için bk. Ahmed Cevdet Paşa, Belâgat-ı Osmâniyye, nşr. Turgut Karabey- Mehmet Atalay (Ankara: Akçă̆ Yayınları, 2017) 130-131.

23 Ahmed Bîcân, Müntehâ- fusûsu'l-hikem üzerine bir çalışma, 431.

24 Eserin bazı yazma nüshalarını şu şekilde sıralamak mümkündür: Süleymaniye Kütüphanesi Kılıç Ali Paşa, nr. 630; Hacı Mahmud Efendi, nr. 2267; Yazma Bağışlar, nr. 07585; Yazma Bağıșlar, nr. 07585; İbb Atatürk Kitaplığ1 nr. MC Yz K0108; Tercüman Gazetesi Kütüphanesi Türkçe Yazmaları, nr. 204; Milli Kütüphane, 06 Mil Yz A 3271 .

25 Bahsedilen iki Müntehâ'nın farklılıklarını göstermesi amacıyla Müntehâ I ve Müntehâ II'nin muhtevâ dökümleri Ek-1'de karşılaştırmalı olarak gösterilmiştir. 
şerhçiliğinde ilk defa tatbik edilen bir usuldür. ${ }^{26}$

Eserin sonunda Tezkiretü'l-evliyâ' dan alındığı anlaşılan on altı sûfînin hal ve sözlerinden bahsedilen bir bölüm de mevcûddur. Müntehâ I'de yer alan "Ist1lâhâtu's-sûfiyye" bölümü ise bu kitapta yoktur. Eserde namaz, abdest, gusül, oruç, zekât gibi ibâdetler hakkında bilgiler verilmiş aynı zamanda bu ibadetlerin tasavvufi yorumları da zikredilmiştir. Eserin önemli bir diğer özelliği şudur ki müellifin de dîbâcede belirttiği üzere Yazıcızâde Muhammed Efendi kendisine "Bir tefsîr düzesün"27 demiş ve bunun üzerine Ahmed-i Bîcân on sekiz sûreyi meallerini de vermek sûreti ile hem te'vîlî hem de işarî olarak tefsîr etmiştir. Ve kitabının "Rûm ilinin tamamında emsâlsiz bir tefsîr" olduğunu ifâde etmiştir. ${ }^{28}$ Müellifin âyetleri tefsîr ederken umumiyetle işâriî tefsîr usulünü kullandığı görülmektedir. Ahmed-i Bîcân, bir tefsîr olarak kaleme aldığını ifâde ettiğ $i^{29}$ Müntehâ II adlı eserini üç türlü "ibâre” ile yazdığını ifâde

26 Bu durumun daha iyi anlaşılması için, Ahmed-i Bîcân'ın yazma hâlindeki eserinden bir bölüm nakletmek mümkündür: "Hikmet-i kalbiyye - Kelime-i Şu'aybiyye. Kaçan bir peygamber zâhir olduysa tarîk-i belâda Allâh için, emr-i ilâhî Nûh'u iktizâ etti ki bundan sonra bir peygamber gele ki müştâk-1 visâl ola. Zîrâ Hakk'ın kapusu sâiller içün meftûhdur ve belâsı âşılar içün fütûhtur. Pes Şu'ayb cihâna geldi ve nebî oldu. Kavmine söyledi, onları Hakk'a da'vet eyledi iştiyâk-1 tâmm ile. Bu şevkten ötürüdür ki üç yüz yıl ağladı. Her yüzyılda bir kez gözsüz oldu, gözü geri açıldı. Hakk Teâlâ, Şu'ayba hıtâb kıldı, eyitti: Yâ Şu'ayb! Senin için uçmakta bir ev yaptım ak inciden, bâtınında zâhiri gözükür ve zâhirinde bâtını gözükür ve arşın mukabelesindedir Kapısı benim likâma açılır, ebeden sana yapılmaz, dedi. Şu'aybın rûhu ismü'z-zât nûrundandır ki Mâcid'dir ve onun içün kavmine şerê̂f idi ve hatîbü'l-enbiyâ idi. Ve kalbi ismü’s-sıfât nûrundandır ki Kerîm'dir. Onun içün halka keremler ederdi. Ve nefsi ismü'l-fí ‘lin ikisinin nûrundandır ki bir Hakem idi. Onun içün halka hükmederdi. Ve biri Muksit'dir. Onun içün halka mîzânı tamâm, berâber edin, derdi. Bilmek gerektir ki âşığa vâcibdir ki her ne kim ma 'şûkdan gelirse cefadan, vefadan râzî olup emrine mutî‘ ola. Zîrâ âşık letafetten kopar ve her nesne kim latîf ola nâ-çâr latîf tabiatlı kişiye ulaşır. Zîrâ âşk bir illettir ki yeyni cânlarda olur. Pes her kim âşık oldu; âlem-i gaybden ve âlem-i şehâdetden her ne vâki' olsa lâ-übâlî var kendini ona vura, hiç sonun endişe kılmaya ve hem cânından üşenmeye, cânân için bî-cân ola ve bir günde bin kere başın kademi altına ala. Medh, zemm, redd, kabûl, a'tâ ve belâ âşık katında bir ola ve vakit olur ki; âşıktan havf ü recâ sıkıntıları götürülür. Zîrâ ki havf ü recâ ya mâzîde yâhud müstakbeldedir. Âşık, bahr-i ahadiyyetde gark olmuştur. Mâzî vü müstakbel kaygusu ona kalmamıștır. HIKÂYE: Ka 'bü'l-ahbâr eyitir: Kaçan kim Medyen halkı kâfir oldular; Hakk Teâlâ Şu 'ayb'a Cebrâil'i veribidi. Şu'ayb peygamber İbrâhim neslinden idi. Cebrâil eyitti: Yâ Şu'ayb! Hakk Teâlâ ôyle buyurdu ki Medyen kavmi saneme taparlar, onları îmâna da 'vet eylesin, dedi. Meğer ol kavmin beylerinin adı; Ebî Câdû, Hevvez, Huttî, Kelemen ve Kureyşiyyât idi. Müneccimler bu isimlerin tabî‘ atına nazar eylediler. Bunları hurûf kıldılar. Pes Şu'ayb onları da'vet eyledi. Onlar imâna gelmediler, inkârları dahi ziyâde oldu. İbn Abbâs eyitti: Hakk Teâlâ, onlara cehennemden od veribidi. Onlar kaçtılar mağaralara ve girdiler mağaraların içi taşından dahi ıssı oldu. Ondan çıkıp sahrâlara kaçtılar. Hakk Teâlâ bir yalın veribidi onları helâk eyledi. Mü'minler bu hikmeti görüp Hakk Teâlâ'ya şükrettiler. Şu'ayb peygamber, kâfirlerin malını mü'minlere kısmet eyledi. Ve Şu'aybın üç yüz yıl ömrü oldu. Ka 'be'de vefât eyledi ve anda defn eylediler. [Bu dünya yurdunun hâli budur, ibret alınız ey basiret sâhipleri]. Yazıcızâde, Ahmed-i Bîcân, Müntehâ II, Ankara: Milli Kütüphane, (06 Mil Yz A 3271), 63b vd.

27 Yazıcızâde, Ahmed-i Bîcân, Müntehâ II (İstanbul: Süleymaniye Kütüphanesi, Yazma Bağışlar, 7585), 4a.

28 Ahmed-i Bîcân, Müntehâ II (Yazma Bağışlar, 7585), 4a.

29 Ahmed-i Bîcân, Müntehâ II (Yazma Bağışlar, 7585), 4a. 
ederek bu ibâre türlerinin "teşri'“", "tahkîk" ve "te'vîl” olduğunu söyler. ${ }^{30}$ Osmanlı tasavvufî tefsîr geleneğinin ilk örneklerinden biri olma vasfina sahip olan Müntehâ II' deki tefsîr üslûp ve muhtevâsı hakkında bilgi vermek amacıyla Ek-2'de ilgili kitaptaki Yâsîn Sûresi tefsîri numûne olarak dercedilmiştir. Yâsîn Sûresi'nin seçilmesinin sebebi Yâsîn Sûresi'ne dâir Osmanlı âlimlerinin çokça eser kaleme almış olmalarıdır. ${ }^{31} \mathrm{Bu}$ rağbetin sebepleri arasında îmânî konulara dâir muhtevâsı ve faziletleri hakkındaki rivâyetler gösterilebilir. ${ }^{32}$ Yazdığı Envâru'l-âş̧ıîn adlı eser ile Osmanlı coğrafyasında derin tesirler bırakmış Ahmed-i Bîcân'ın işârî tefsirinin sunulması literatüre katkı sağlayacaktır.

\section{Sonuç}

Netice itibarı ile; Yazıcızâde Kardeşlerin Fusûsu'l-hikem şerhi hüviyetindeki eserleri özellikle çağdaş kaynaklarda ifâde edildiği gibi Müeyyedüddîn-i Cendî’nin Fusûsu'l-hikem şerhine yazılmış bir ta'lîkât değildir. Ayrıca yine kaynaklarda tek eser olarak telakki edilen Ahmed-i Bîcân'a ait aynı adı taşıyan Müntehâ adlı eserler birbirlerinden farklıdırlar. İlk olarak Behçet Gönül (Behçet Necatigil) tarafından fark edilen; lâkin hakkında yeterli bilgi bulunmayan bu ayrım iki eserin içerik analizi yapılarak ortaya konulmuştur. Bu eserlerden ilki 857/1453 tarihinde, diğeri ise 870/1465 tarihinde kaleme alınmıştır. Sonradan yazılanı aynı zamanda müstakil bir işârî tefsîr bölümü ihtivâ etmektedir. Yine bu eser bu çalışmada kavramlaştırıldığı ve tavsîf edildiği şekli ile bir "Kıssalı-Fusûs” örneğidir. Yazıcızâde Kardeşler, kendilerinden evvelki şerhlerde takip edilmeyen bir usûl olarak Fusûsu'l-hikem'in enbiyâ tertibini değiştirmişlerdir. Yazıcızâde Kardeşlerin şerhlerini üslûp ve yaklaşım olarak diğer şerhlerden ayıran en "mümeyyiz" husus ise; İbn Arabî'ye ve Fusûsu'l-hikem'e bakış açıları ile yön verdikleri; İbn Arabî'yi “ma'zûr ve me'mûr”; Fusûsu'l-hikem'i ise ma‘sûm olarak telakki ederek sürdürdükleri tenkîdî üslûplarıdır. Binâenaleyh; Yazıcızâde Kardeşlerin Fusûsu'l-hikem şerhleri herhangi diğer bir eser üzerine yazılmış birer ta 'lîkât değil; bilakis tasnîf, tertîb ve üslûpları ile müstakil birer eser hüviyetindedirler.

30 “Ammâ ben miskîn Ahmed-i Bîcân ulemânın esrârını ve urefânın envârını kîl be kîl âlemin evvelinden tâ âhirine değin üç türlü ibâretle beyân eyledim. Biri teşri' ve biri tahkîk ve biri de te'vîldir ki rûh-1 uşşâk bu kitapla müşerref olalar inşâallâhü Teâlâ.” Ahmed-i Bîcân, Müntehâ II (Yazma Bağışlar, 7585), 3b.; Bu kavramlara Ahmed-i Bîcân'ın yüklediği anlamlar hakkında ayrıntılı bilgi için bk. Mehmet Bilal Yamak, Yazıcızâde Kardeşlerin Tasavvufí Görüşleri ve Osmanlı ya Tesirleri (İstanbul: İstanbul Üniversitesi, Sosyal Bilimler Enstitüsü, Doktora Tezi, 2021), 153 vd.

31 Şükrü Maden, “Osmanlılar'da Yâsîn Sûresi Tefsir Geleneği ve Ebû İshâkzâde Mehmed Es'ad Efendi'nin Yâsîn Sûresi Tefsiri”, Osmanlı Döneminde Tefsir, haz. Hidayet Aydar vd. (İstanbul: Ensar Neşriyat, 2018), 255.

32 Maden, “Osmanlılar'da Yâsîn Sûresi Tefsir Geleneği”, 255. 


\section{EK-1: Müntehâ I ve Müntehâ II'nin Karşılaştırmalı Muhtevâ Dökümleri: ${ }^{33}$}

\section{MÜNTEHÂ I}

- Sebeb-i te'lîf-i kitâb

- Fasl fî tahlîk-i Âdem

- Der beyân-1 Sifâtu'r-rûh fî Âdem

- Fasl fî Tevbe-i Âdem

- Fasl der-beyân-1 tertîbi'l-mevcûdât

- Fasl-1 hikmet-i ilâhiyye fî kelime-i Âdemiyye

- Fasl fî hikmet-i nakşiyye fî kelime-i Şît

- [Fass] fî hikmet-i ahadiyye [fî] kelime-i Hûdiyye

- Kıssa-i hikmet-i futûhiyye fî kelime-i Sâlihiyye

- Kıssa-i hikmet-i kuddûsiyye fî kelime-i İdrîsiyye

- Kıssa-i hikmet-i subbûhiyye fî kelime-i Nûhiyye

- Kıssa-i hikmet-i müheymiyye [fî kelime-i] İbrâhîmiyye

- Kıssa-i Aliyye fî kelime-i İsmâiliyye

- Kıssa-i hikmet-i Hakîkiyye fî Kelime-i İshâkiyye

- Kıssa-i hikmet-i rûhiyye fî kelime-i Ya'kûbiyye

- Fass-1 hikmet-i nûriyye fî kelime-i Yûsufiyye

- Fass-1 hikmet-i gaybiyye fî kelime-i Eyyûbiyye

- Fass-1 hikmet-i kalbiyye fî kelime-i Şuaybiyye

- Fass-1 hikmet-i ulviyye fí kelime-i Mûseviyye

- Fass-1 hikmet-i imâmiyye fî kelime-i Hârûniyye

- Fass fî hikmet-i inâsiyye fî kelime-i İlyâsiyye

- Bu fasıl keşf-i kuburu ve ervâhı beyân eder

- Fass fî hikmet-i vücûdiyye fî kelime-i Dâvûdiyye

- Münâcaat-i Dâvûd Peygamber

- Fass-1 hikmet-i Rahmâniyye fî kelime-i Süleymâniyye

- Fass fî hikmet-i kaderiyye fî kelime-i Uzeyriyye

- Fass fî hikmet-i nefesiye fî kelme-i Yûnusiyye

- Fass-1 hikmet-i nefesiyye fî kelime-i Zekeriyyâiyye

- Fass-1 hikmet-i celâliyye fî kelime-i Yahyâviyye

- Fass-1 hikmet-i nebeviyye fî kelime-i Îseviyye

- Fasl fî mâ yuktebu fî̀'l-İncîl

- Hadîs-i ref'-i Îsâ ile's-semâ

- Fass-1 hikmet-i ferdiyye fî kelime-i Muhammediyye

- Hadîsü'l-Mi'râc

- Fasl fî esrâri’l-vahy

- Hicretü'n-nebî

- Fasl fî nüzûli'n-nebîyyi bi’l-Medîne

- Vefâtü'n-nebî

- Vefât-1 Fâtımatü'z-zehrâ

- Vefât-1 Ebû Bekr

- Vefât-1 Ömer

- Vefât-1 Osmân

- Vefât-1 Alî
MÜNTEHÂA II

- Mukaddime

- Sebeb-i te'lîf

- Usûl-i tel'lîf

- İsm-i te'lîf

- Muhtevâ-yı te'lîf

- Bazı mesâil-i vahdet-i vücûd- Tevhîd-i zâtın delilleri - Fenâ - Vücûd

- Mahsûsât ve ma'kûlâtın bazı mesâili cem' edip zâhir ve bâtın itikatları nazara açmak- Kelam, felsefe, tahkîk- Kelâmi bazı meseleler

- Beyân-1 tertîb-i mevcûdât (Tertîb-i âlem, Halk-1

Âdem, İblîs, Halk-1 Havvâ, Ehl-i beyt, Hz. Âdem ve

Havvâ'nın cennetteki ahvâli)

- Kıyamet gününde dünyanın bir kadın olarak getiriliși- Tevbe-i Âdem, Kabûl-i tevbe-i Âdem

- Fusûsu'l-hikem Şerhi- Fasslar: Şit, İdrîs, Nûh, Hûd, Sâlih, İbrâhim, İsmâil, İshâk, Yakûb, Yûsuf, Eyyûb, Şuayb, Mûsâ, Hârûn, İlyâs, Dâvûd, Uzeyr, Yûnus,

Zekeriyya, Yahyâ, Îsâ, Muhammed (s.a.v.).

- Kur'ân'a Göre Mi'râc

- Hadîs-i Mi'râc

- Rü’yetullâh

• Emvâl-i Gazâ

- Eslihat-i Nebî

- Edeb-i Gazâ

- Deniz Gazâsı

- Şehitlerin Namazı

- Gemiye Binmek

- Şehitler

- Gâzînin iki düşmanı, Nefs, Halk-1 kâinât, Helâk-i

kâinât, Kıyâmet alâmetleri, Masnûatın tertibinin

tahkiki, Kıyamet alâmetlerinin tahkîki, Kiyâmet, Hacc

Suresi 2. Ayeti Tefsîri

- Cehennem - Cennet- Rü’yetullâh- Fezâil-i Nebî

- İnsân-1 Kâmîl - Hakîkat-i Muhammedîyye -

Zikrullâh - Aşk

- Evliyâ

- İstiâzenin tefsîri

- Besmelenin fazileti

- Kur'ân'ın fazileti

- Esrâr-1 hurûf

- Besmele

- Fatiha

- Salavât Ayeti

33 Ahmed Bîcân, Müntehâ-fusûsu'l-hikem üzerine bir çalışma, nşr. Ayşe Beyazıt (İstanbul: İnsan Yayınları, 2011). Ve Ahmed-i Bîcân, Müntehâ II (Milli Kütüphane, 06 Mil Yz A 3271). 


\section{MÜNTEHÂ I}

- Vefât-1 Hasan-Huseyn

- Fasl fî 1stılâhât-1 sûfiyye

- Fasl fî Menâzili’s-sâirîn

- Fasl fî't-temsîl

- Fasl fî inşikâki'l-kamer

- Fasl fî sırri'l-mirâc

- Fasl fî̀ sırri'l-vuzû'

- Fasl fî sırri's-salâti'l-hams

- Fasl fî sırri'l-hicreti min-Mekke ile'l-Medîne

- Fasl fî sırri's-salât

- Fasl fî sırri tahvîli'l-kıbleti min Beyti'l-mukaddesi ile'l-Ka'beti

- Fasl fî sırri'z-zekât

- Fasl fî sırri's-slyâm

- Fasl fí esrâri'l-Hacc

- Fasl fî sırrü'z-zikr

- Fasl fî cihâdi'n-nebî s.a.v.

- Fasl fî sırr-i vefât-i Resûl s.a.v.

- Fasl fî fezâili's-salavât ale'n-nebiyyi s.a.v.

- Fasl fî temsîl-i Ashâb-i Resûlullâh s.a.v.

- Fasl fî Tezkireti'l-Enbiyâ

- Fasl fî eşrâti's-sâati

- Fasl fî hurûci'd-deccâl

- Fasl fî nüzûl-i Îsâ

• Fasl fî hurûci'd-dâbbetü'l-arz

- Fasl fî tulû'i'ş-şems min mağribihâ

- Fasl fî sedd-i bâbü’t-tevbe

- Fasl fî nefhi's-sûr

- Fasl fi'l-haşr

- Fasl fî tebdîli'l-arz ve's-semâvât

- Fasl fî̀ livâi'l-hamd

- Fasl fi'ş-şefâat

- Fasl fi'l-hisâb

- Fasl fî'l-kitâb

- Fasl fi'l-mîzân

- Fasl fî cehennem ve derekâtihî

- Fasl fi'l-havz

- Fasl fi'l-Hûr

- Fasl fî vildâni'l-cenne

- Fasl fi'l-gilmân

- Fasl fî enhâri'l-cenne

- Fasl fĩ rü'yetullâh

- Fasl fî merâtibi'l-insân

- Fasl fî sırri'l-hûr

- Fasl fî'l-vildân ve'l-gilmân

- Fasl fî sırri'l-enhâr

• Hâtimetü'l-kitâb

\section{MÜNTEHÂA II}

• Tefsîr Bölümü (Yâsîn, Fetih, Rahmân, Vâkıa, Mülk, Duhâ, İnşirâh, Tîn, Alak, Beyyine, Zilzâl, Âdiyât, Kâria, Tekâsür, Hümeze, Fîl, İhlâs, Felâk, Nâs sûreleri).

- Hicret-i Nebî

- Vefât-1 Nebî

• Vefât-1 Fatımatü'z-zehrâ

- Vefât-1 Ebû Bekir

- Vefât-1 Ömer

- Vefât-1 Osman

- Vefât-1 Ali

- Vefât-1 Hasan-Hüseyin

• Evlâd-i Rasûl

• Ezvâc-i Rasûl

• Așere-i Mübeşşere

• Evliyâ

- Nasihat

• Hâtime 


\section{EK-2: Ahmed-i Bîcân'ın Müntehâ II Adlı Eserinin Tefsîr Kısmından Yâsîn Sûresi Tefsîri ${ }^{34}$}

[81a]

Ve ba'dehû geldük imdi Sûre-i Yâsîn otuz iki âyetdür, Mekke'de geldi. Ve ba'zılar aydür otuz üç âyetdür ve yidi yüz yigirmi kelimedür. Ve harfleri üç bin harfdür. Peygamber aleyhi’sselâm ayıtdı her kim Yâsîn Sûresin okusa Hak Teâlâ ol kişinün cemî‘-i günahlarını yarlığar. Ve on iki kez hatm itmişce müzdü

[81b]

vardur. Eğer bir sayrınun katında Yâsîn okunsa her harfine on ferişteh gelür. Ol sayrınun katında dururlar anunçün istiğfâr getürürler. Ve her kim sayru olsa kendüsi Yâsîn Sûresin okusa sekerât-1 mevtden emîn ola. Ve nakildür ki Kur'ân okuyan mü'minlere Kur'an gele ayda yâ mü'min sen beni gice ve gündüz okurdun ben Kur'ânven diye bâşına tâc uruben, eğnine hil'ât giyüre cennete ele gide. Ve ba 'dehû "hakîm”, hâkim ma'nîsine gelür. İmdî başladuk

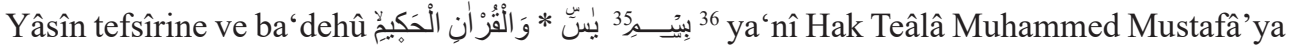
Yâsîn dimek "Yâ İnsan!" dimekdur yâhud "Yâ Racül!" dimekdür yâhud "Yâ Muhammed!" dimekdür. Ve ba 'dehû Hak Teâlâ Kur’ân’a and içer. Sebeb-i nüzûl-i sûre oldur ki Peygamber’e kâfirler ayıttılar yalan söylersin Hak Teâlâ seni peygamberliğe viribimedi. Sen kendüzünden söylersin didiler. Hak Teâlâ Kur'ân'a and içer aydür Yâ Muhammed! Sen mürsellerdensin, ekmel-i enbiyâsın, kâfirler seni bilmezlerse sen gussalanma ki Hak Teâlâ seni peygamberliğe viribidi. Kur'ân hakkıçün ki sen muhkemsin bozulmazsın. عََّْ 37 Hak budur ki Yâ Muhammed sen mürsellerdensin. عَى صِرَاطِ

[82a]

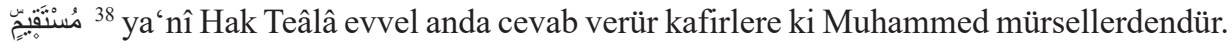
Ya'nî İslâm dîni üzerinesin. Dahi yâ Muhammed sen şol nesnenün üzerinesin kim sırât-1 mustakîmdür. İmdi istikâmet-i aynî tefrîde işâret itmekdür. İmdi istikâmetden murâd cemî‘-i kuvve hudud-1 şer'iyye üzerine sebât bulmakdur. Ve hidâyet taleb itmekdür. Eyle olsa hidâyet ikiye munkasımdur. Biri ma'rifet taleb itmekdür delîl ile ve bir bâtınını tasfiye itmekdür riyâzet ile. İstikâmet üç derecedür biri ictihâd üzerine mustakîm olmakdur. İkinci derece ahvâli

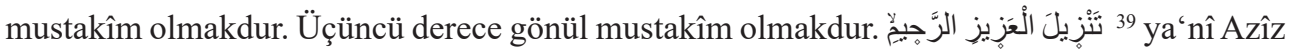

34 Ahmed-i Bîcân, Müntehâ II (İstanbul: Süleymaniye Kütüphanesi, Yazma Bağışlar, 7585), 81a-102b.

35 Yâsîn 36/1-2.

36 "Rahmân ve Rahîm olan Allah'ın adıyla."

37 Yâsîn 36/3.

38 Yâsîn 36/4.

39 Yâsîn 36/5. 
Rahîm Tanrı Kur'ân'1 sana indürüb durur. مَا أنْذِرَ

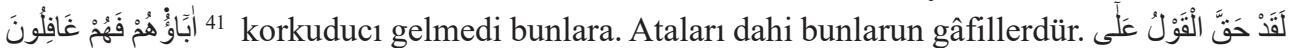
لألَ 42 be-dürüstî sâbit olub durur sözümüz bunlarun ekseri üzerine. Pes bunlar

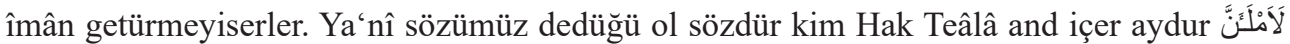

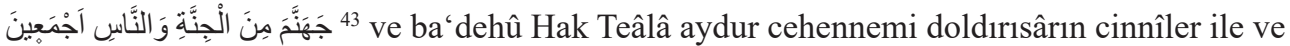
Âdemler ile.

Bilmek gerekdür ki cinnîler hevâyîlerdür. Hak Teâlâ anları odun yalınından yarattı. Dürlü dürlü suretlere girürler. Kimi âdem başlu kaplan gövdelü ve kimi öküz başlu ve kimi yılan gövdelü ve kimi deve başlu ağızlarından yalın çıkar. Kimi ejderhâ gibi haykırur ve kimi dahi arslan gibi ekrer. Kimi de âdem gibi söyler. Vakt olur ki âdemlere gözükürler vakt olur ki

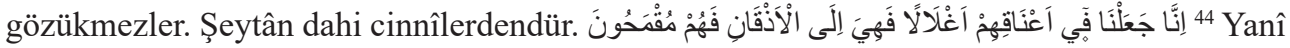
bunlarun azgınlık zencîrini boyunlarına berkittük enekleri altına değin çıkub durur. Ya'nî önlerine bakamayalar, âciz kalalar. 45 Ya'nî biz kâfirlerün önlerini sedd kılduk, ve arkalarını dahi sedd kılduk, yollarını bağlattuk ve

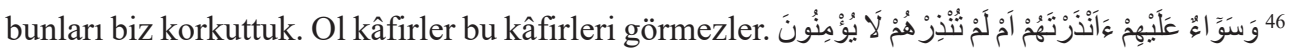
Ya'nî Hak Teâlâ aydur yâ Muhammed berâberdür kâfirlerün üzerine gerekse korkut gerekse

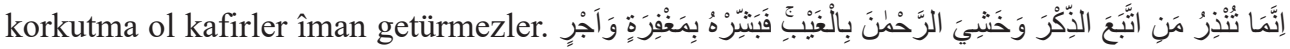
كَِّ ${ }^{47}$ ya'nî Hak Teâlâ aydur yâ Muhammed be-dürustî

senün korkutman şol kişileredür kim Kur'ân'a tâbi‘ olalar. Ve dahi Hak Teâlâ'dan korkalar ve dahi Hak Teâlâ'dan korkalar. Ve dahi yâ Muhammed ol kişilere muştula ki Hak Teâlâ anlara

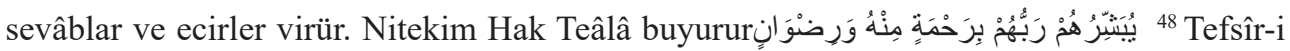
Kebîr'de aydur bu beşâretde bir nîce vech vardur. Biri budur ki Hak Teâlâ bunlara rahmetin beşâret ider. Bunlarun ferahı ve sürûrı rahmeti ile oldı. Bir vech dahi budur ki muhakkikler aydurlar Hak Teâlâ bunlara kendüyi muştılar. İmdi pes bunlar Rabb ile müşerref oldılar. Ferahları ve sürûrları Hakk-1 mutlak ile oldı. Ve şol kimseler ki işbu mertebeye irişmedi ve nefesleri temâm fâide virmedi. Ol kişinun ferahı ve sürûrı mecmu'1si ile oldı. İmdi beşâret

40 Yâsîn 36/6.

41 Yâsîn 36/6.

42 Yâsîn 36/7.

43 Secde 32/13

44 Yâsîn 36/8.

45 Yâsîn 36/9.

46 Yâsîn 36/10.

47 Yâsîn 36/11.

48 Tevbe $9 / 21$. 
rahmet ile ve ihsân ile olur. Bir vech dahi budur ki her kişi kim bir nesneyi muştular kendüye göre olur. İmdi bunda muştulayan Hak Teâlâ'dur ki Ekremü'l-ekremîn'dir. Öyle olsa beşâret-i

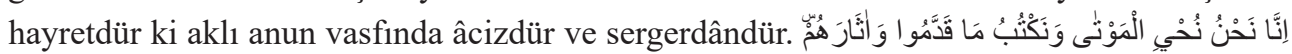
ya'nî Yâ Muhammed eğer bu kavmün seni gerçeklemezlerse

ve âhirete îmân getürmezlerse imdi sen sabreyle kim biz hakîkatde bu olanları gene koparuruz ve kendülerden önden her ne amel kim kıldılarsa ânı defter idüb saklarlar. Ya'nî iki ferişteh komışuzdur ki anlarun hayrını ve şerrini yazalar. Ol feriştehlerün adı Kirâmen

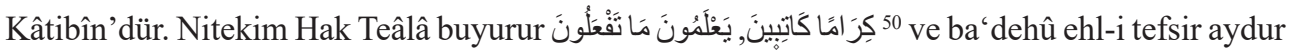
insanda beş feriştehler vardur. Biri ale'd-devâm durur ikisi dahi sağında ve ikisi dahi solında. Sağındağı hasenâtın yazar ve solundağı seyyiâtın yazar. Ol feriştehler ikisi sabâh gelür ve ikisi dahi ikindüden sonra gelür amellerin alurlar göklere giderler. Ammâ sağındağı müvekkeldür solundağına eğer suâl iderlerse Münker ve Nekir iki feriştehlerdür bu cemî‘-i halka nîce irüşürler. Bir def'ada cevab budur kî Cebrâil ve Mîkâîl ve Azrâil bir def'ada yüz binden artuk

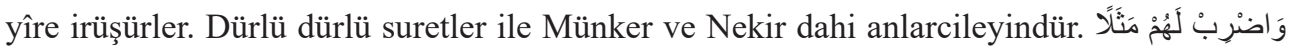

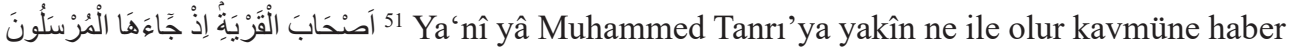
vir. İmdi anlarun misâlleri ol ashâb-1 karye gibidür ki Resûlleri anlara geldiler. Ve ba'dehû

[84a]

karye didüği Antâkiyye'dür. Ve Îsâ Peygamber Resûlleri ol kavme geldiler.

İmdi fasl-1 evvel bilmek gerekdür ki şerî‘ atini bildürür peygamberlerün. Âdem Peygamberün şerî‘ati buyıdı kim iki da‘vîcisi gelseler, Âdem Peygamber buyurdı kurbân iderlerdi. Gökden od geldürdü, oda bırağurdı kimün ki kurbânı oda yansa anun sözü hakdur dirlerdi.

Ve Nûh'un dahi şerî‘ati oldı kim kaçan iki kişi gelseler, da'vî eyleseler, ellerin gemisine yapışdururlardı ve eğer ol gemi hareket eylerse bilürlerdi ki hakdur, eğer hareket eylemezse bâtıldur dirlerdi.

Ve İbrâhim'un şerî‘ati dahi oldur kim kaçan iki kişi da'vîye gelseler od yakarlardı. Elini ol oda sokarlardı eğer yanarsa bilürlerdi kim bâtıldur.

Ve dahi Dâvud'un dahi şerî‘atin bildürür ki evi öninde bir zencîr asılub dururdı. Kaçan iki kişi da'vîci gelseler kankısı ol zencîre irüşürse hakdur ve dahi zencîr yukaru kalkarsa erüşmezse bâtıldur dirlerdi.

Ve Süleymân'un şerî‘ati dahi oldı kim evinde bir çukur var idi. Kaçan iki da‘vîci gelseler ayağın ol çukura sokarlardı. Eğer çukura batarsa bilürlerdi ki hakdur. Eğer

49 Yâsîn 36/12.

50 İnfitâr 82/11-12.

51 Yâsîn 36/13. 
[84b]

batmazsa bâtıldur dirlerdi.

Ve Zekeriyyâ'nun şerî‘ati olıdı kim hadîdden bir kalem eylemişdi. Eğer iki da‘vîci gelseler adlarını ol kaleme yazardı, suya bırağurdı. Eğer su ol kalemi alur giderse bilürlerdi ki hakdur. Eğer su almazsa bâtıldur dirlerdi.

Ve Mûsâ'nun dahi şerî‘ati olıdı kim Tevrât ile hükmi derdi. Nîce muvâfık ise ana göre cevâb buyurırdı.

Ve Îsâ'nun şerî‘ati olıdı kim İncîl ile hükmiderdi. Nice münâsib ise.

Ve Muhammed Mustafâ'nun şerî‘ati olıdı kim kaçan iki da'vîci gelseler, da‘vî idenden iki tanuk isterdi. Eğer iki tanuk bulunursa hükm iderdi ki hakdur, ve eğer ol da'vî eyleyenün tanukları olmasa ol biri and içerdi. Nitekim Hak Teâlâ buyurur "el-beyyinetü alâ'l-müdde ' ve'l-yemînü alâ men enkerahû." "52 Eyle olsa Muhammed Mustafâ'nun Şerî'atı anlardan efdal oldı.

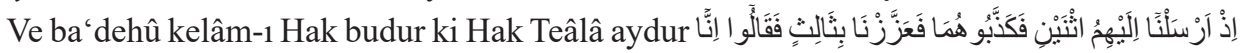

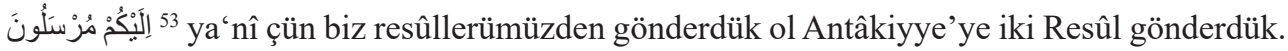
Biri Yahyâ ve biri Yûnus idi. Antâkiyye kavmine gelüb da‘vet kıldılar. Ol kavm ikisin dahi yalanladılar. Ya'nî Yahyâ'ya

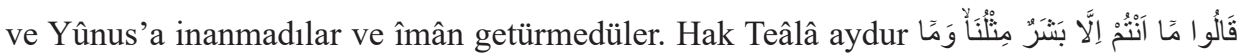

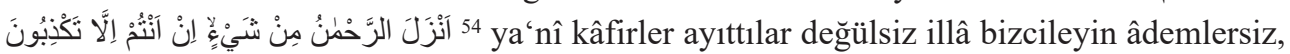
mürseller değülsiz yalan söylersiz didiler. Hak Teâlâ sizleri mürselliğe viribimedi diyü şekk

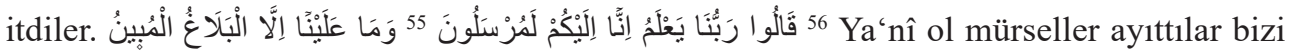
Tanrımuz bilür ki biz Tanrı'dan geldük mürsellerüz bizüm üzerümüze lâzım küllî budur ki

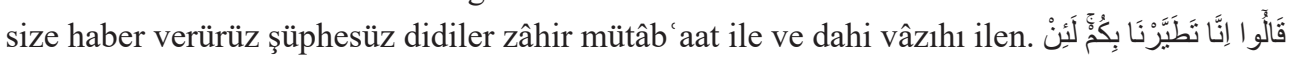

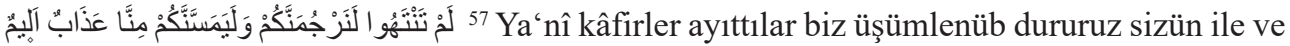
eğer siz bu sözlerden dinmesenüz sizi taş ile depelerüz ve size bizden katı azâb erişür şöyle bile

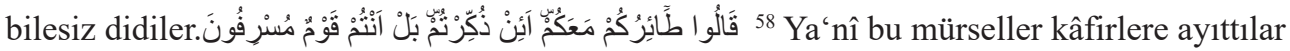
sizün üşümmlüğünüz kendüzünüzdedür. Biz size nasîhat idüb îmâna gelün didüğümüz içün sizler bizi eşümmî dutarsız. Biz üşümmler değülüz belki siz kavmsiz hadden geçüb durursız. İnsâfunuz yokdur müsriflerdensiz.

\footnotetext{
52 "Bir husûsu iddiâ edene iddiasını delillendirmek düşer. İnkâr eden ise kendisinden istenirse yemin eder."

53 Yâsîn 36/14.

54 Yâsîn 36/15.

55 Yâsîn 36/16.

56 Yâsîn 36/17.

57 Yâsîn 36/18.

58 Yâsîn 36/19.
} 
60 Ve ba'dehû Hak Teâlâ aydur Habîb-i Neccâr dirlerdi şehr içinde bir kişi segirdi segirdi geldi aydur ya halâyık mürsellere uyun ki sizden ücret dilemezler ve anlarun yolu toğr1 yoldur.

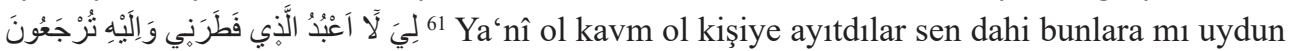
diyince ol kişi ayıtdı benüm neme gerek kim ol Tanrı'ya tapmayam kim beni yaratdı ve sizün

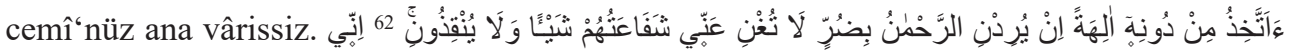
Kâfirler ol kişiye ayıtdılar biz gene dönerüz diyince kâfirlere ol kişi ayıtdı Tanrı'dan gayrı bir dahi tanrı mı vardur? Dinden döneyin imdi Tanrı'nun elinden gelür ki hayr ve şer işleye. Ol sizün putlarunuz elinden gelmez ki hayr ve şer işleye. Eğer ben size uyarsam

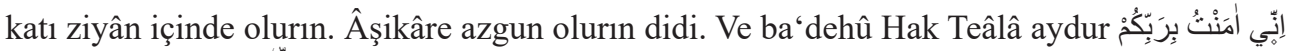

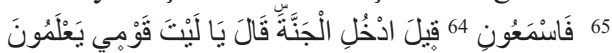

[86a]

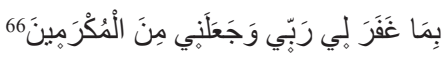

Ya‘nî ol kişi ayıtdı ben îman getürdüm sizi yaradan Tanrı'ya. Beni işidün sözüm hakdur. Allah'a sizler dahi îman getürün. Ol kâfirler bu sözü işitdiler ol kişiye kakıdılar ol kişiyi öldürdüler. Hak Teâlâ ol kişiye feriştehler viribidi. Ol kişinün cânını kabz idüb uçmağa iletdiler. Ol kişi ayıtdı n'olaydı benüm kavmüm beni bilelerdi ki Hak Teâlâ beni yarlığadı ve hürmetlü

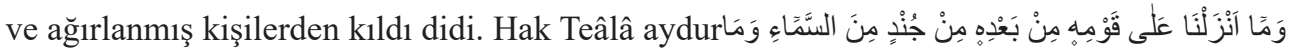
年 68 Ya'nî Hak Teâlâ ol kişinün kavmine aydur biz gökden feriştehler çerisin indürmeğe muhtâç olmaduk ve dahi indürmedük. Pes eyle olsa ol

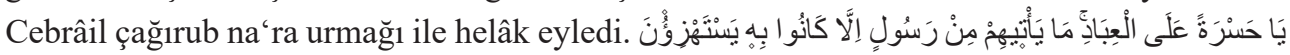
${ }^{69}$ Ya'nî hasretlik ve peşîmanlık bu halk üzerine gelmezdi. Kaçan bunlara bir peygamber gelse

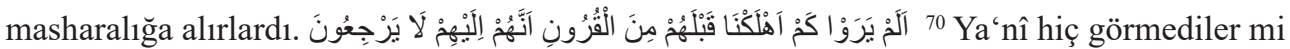
Mekke ehlini nice nice helâk eyledük. Bunlardan önden helâk

59 Yâsîn 36/20.

60 Yâsîn 36/21.

61 Yâsîn 36/22.

62 Yâsîn 36/23.

63 Yâsîn 36/24.

64 Yâsîn 36/25.

65 Yâsîn 36/26.

66 Yâsîn 36/27.

67 Yâsîn 36/28.

68 Yâsîn 36/29.

69 Yâsîn 36/30.

70 Yâsîn 36/31. 
[86b]

oldılar. Ayruk dünyâya gelmediler.

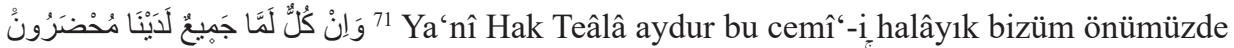

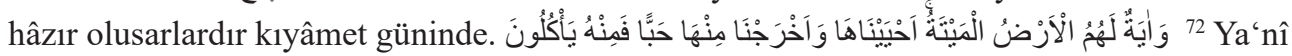
bunlara delâlet ider şol yirdeki ölmişdür biz ânı gine diriltdük ve ol yirden dâneler çıkarduk.

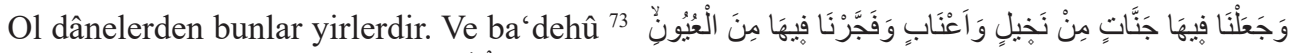

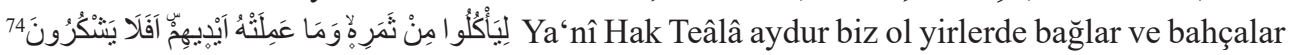
bitürdük. Ol bahçalarda envâ‘ ile yimişlerden yidiler ve ol yirlerde sular akıtduk ki bunlarun elinden gelmez ki eyle ideler idi. Ve ba'dehû Hak Teâlâ aydur biz anlara bunca ni'metleri virdük. Anlar bize şükr itmezler. İmdi şükrün ma‘nâsı üçdür. Biri ni‘metullâhı bilmekdür. Ve

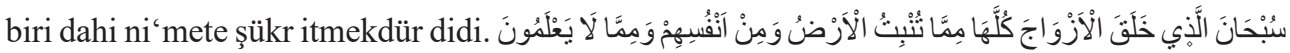
${ }^{75}$ Ya'nî Hak Teâlâ oldur ki arû ve mutahhar pâdişâhdur. Ve cemî‘-i ervâhı ol yaratdı ve cemî‘-i hayvânı ol yaratdı ve dürlü dürlü yimişleri ol yaratdı ve cemî‘si temâm kemâl üzerinedür.

Ve ba'dehû bilmek gerekdür ki rûhun kemâli bedenün noksânına sebebdür. İmdi şol nesneler ki cisme ta'allukdür cemî'i şekâvetdür. Ve şol nesne kim rûha ta'allukdür cemî'si saâdetdür. İmdi bu hâl hâsıl olmağa makâm-1 ferâgat şartdur. Ve ferâgatun mâni‘i dört nesnedür. Evvel halka ihtilât itmekdür, ikinci taleb-i dünyâdur, üçünci ârzû-yı nefsdür, dördünci şeytân vesvesesidür. İmdi ihtilâtı terk eylemek uzlet ile olur, dünyâyı terk eylemek kanâat ile olur, nefs arzuların terk eylemek nefse muhâlefet ile olur ve ba'dehû vesveseleri terk eylemek Hak'dan yardım istemek ile olur. Ve aydurlar ki er kişi avret tonın geymek ile avret olmaz. Nitekim bir kişi tâc ve hırka geymek ile er olmaz hattâ riyâzet ile ve mücâhede ile nice yıllar nefsi ıslâh itmeyince er olmaz. Ve anun gibi câhil kişiyi ilzâm ideler, ana esrâr-1 ulûmdan ve sünnetlerün hakikatlerinden ana suâl ideler, cevâbında âciz kala, cehlin halka bildürüb halkı andan sovudalar. Ve gayri iltifâtı koyub hakka meşgul olalar. Ve dahi şol nesne kim bunlar bilmezler anları. Dahi Hak Teâlâ yaratdı kemâl üzerinedür. Zîra ervâh

bi'l-külliyye cisminden i'râz eylemez nûrdur. Ale'd-devâm cism ile bile olur nitekim Güneş dördünci gökdedür ammâ nûrı ve şuâ'ı arza muttasıldur. Ammâ sırr-1 rûh âlem-i halkdan

71 Yâsîn 36/32.

72 Yâsîn 36/33.

73 Yâsîn 36/34.

74 Yâsîn 36/35.

75 Yâsîn 36/36. 
değüldür ki ta'rîf itmek mümkin ola. Belki rûh âlem-i ibda'dandur ve rûhun zâtı mücerreddür

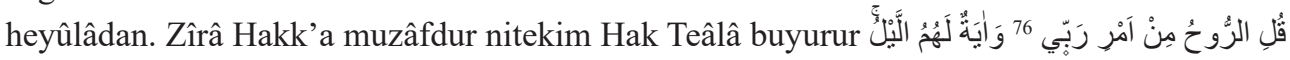

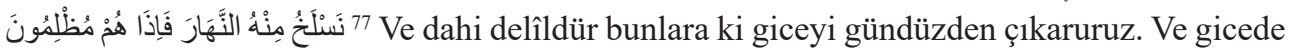
karanlıkda kalurlar zulmet içinde olurlar. Bir zerre aydınlık kalmaz dir.

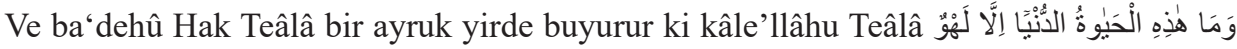

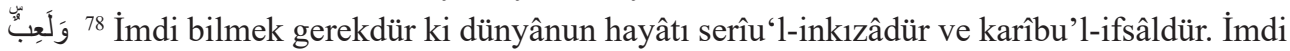
dünyânun misâli şol çok rûzigâr geçürmiş fitnelü ve nazlu bir karı avrete benzer ve ayıbların gizler. Zâhirin gelincikler gibi libâs ile bezeyüb halk arasında nazlar eyler ve şol asılsuz tahayyulâtını harîslerün gönline sermâye eyler. Tâ kim bunlar anun mekr ü tuzağına giriftâr olalar. Ve dahi bir zâlim pâdişâha benzer ki halka nesneler bağışlar ammâ dostluğu

[88a]

yok. Âkibet verdüğin giru alur artuğı depeler ve nîce mal gösteresin aldanmaz, ve ne denlü emân dileyesin vermez. Eğer yüz bin yıl dünyâda olasın ve dünyâyı imâret kılasın, âhir işün ölmekdür. Ve dahi imâretlerun vîrân kalmakdur. İmdi saâdetlü kişi oldur ki dünyânun fânî izzetine ve mevhûm devletine mağrûr olmayub âhiretün bâkî ni'metine yüz duta. Bu murdâr ve merdûd dünyâ nice kez yakınlık isteyenleri hacâlet eli ile göğsünden kakmışdur. İmdi âkil kişiler dünyâyı yağmur katresinden kabaran kubbeye benzedürler. Ve dahi buludlar gölgesine benzedürler. İmdi uslu kişi kışun yarağın yazın iderler. Ve ölüm kaydın diriyiken görürler. İmdi kuş evvel duzağı fikr itmiyecek sonra boynuna düşicek ne dermân idebile ve çoban uyanuk olmayicak kurd ile koyun hâli hod ma'lûmdur. Ve ba'dehû rusûm-i kevneyn bu kâr-nâme üzeredür ve bu şekledür.

$[88 \mathrm{~b}]^{79}$

Hikâye: İskender-i Zülkarneyn diledi kim bahr-i muhît dâiresin bile hoş bir kadırga düzdi. İki yıllık yarağı ile mağribden yanadan gönderüb bir hâs reîs bile koşdu ve bir avret dahi bile koşdu. Ve ol kadırga deniz yüzinde bir yıl gitdiler, denizden gayrı nesne görmediler. Andan sonra gine döndiler ol gün bir kadırgaya denizde giderken karşu vardılar savaş eylediler, elîmediler. Andan sonra söyleşdiler biri birisünün dilini dahi bilmediler. Dahi İskender kadırgası ol bir avreti verdiler ol kadırgadan dahi bir er aldılar döndiler. Bir yıldan sonra gine İskender Pâdişâh'a geldiler ve gördükleri acâyiblerden haberler verdiler. Ol kişi Pâdişâh'a armağan

76 İsrâ $17 / 85$.

77 Yâsîn 36/37.

78 Ankebût 29/64.

79 Bu sayfada bir harita bulunmaktadır. Fotoğrafı için bkz: EK-3. 
getürdiler. İskender dahi buyurdı ol kişiye avret eli verdiler ve bunlardan bir oğlan toğdı. Ve ol oğlân büyüdi atasınun ve anasınun öğrendi dilin. Bir gün ol oğlana ayıtdılar atana sor kanden gelürsiz ol sizün ilünüzün hâlinden haber vergil didiler. Ol kişi ayıtdı bizüm bir pâdişâhımuz var idi. Bize iki yıllık azuk verdi ve ayıtdı bir yıl deniz yüzinde gezünüz, görünüz

[89b]

bizden artuk âdem-zâde var mıdur çün. Gitdük zemân ile size uğraduk didi. İmdî âdemzâde gör ki Bârî Teâlâ ne muhît pâdişâhdur ki hezâr-be-hezâr İskender gibi âzâdelerdi var. İmdi hikmet budur ki İskender aydur ki temâmet şarka ve garba hükmiderin benden ulu pâdişâh yokdur dir. Velî bu sözden bu anlanur ki Hak Teâlâ'nun nîce mahlûkâtı vardur ki ne sen anı bilürsün ve ne hod ol seni bilür. Pes maksûd oldur ki kişi kendünün aczini bilüb Hakk’un azametine ikrâr eyleye.

Hikâyet: İskender-i Zülkarneyn ölicek bir altûndan tâbut içine koydılar, yire gömdiler. Ve İskender vasiyyet itdi kim sağ elümi tâbûtumdan taşra koyasız şöyle boş ola. Ve bir elümde bir altundan elma ola. Ya'nî şöyle dimek ola ki cihânı bir top gibi elüme almışdum âhir dünyâdan gitdüm, elümi boş aldum gitdüm dimek ola. Ve kabri üzerinde bir vezîri turu geldi ayıtdı yâ İskender şimdiye değin sen altûnu gizlerdün şimdi uşde altûn seni gizler didi. Ve bir vezîri dahi ayıtdı yâ İskender biz senün ile mahabbet ile buluşduk ve kerâhiyyet ile ayrılduk didi. Ve birisi dahi ayıtdı

[90a]

Yâ İskender biz senün ile mahabbet ile buluşduk ve kerâhiyyet ile ayrulduk didi. Ve birisi dahi ayıtdı yâ İskender dünyâyı bî-haber devşürdün didi. Ve bî-haber gine kodun yirinde dahi gitdün diyu ağladı. Ve birisi dahi ayıtdı nîceleri sen öldürdün idi. Âkıbet seni dahi öldürdüler. Eğer öleceğün bileydün hiç kimseyi öldürmeyeydün didi. Birisi dahi gine ayıtdı yâ İskender kaçan sefere gitsen çoklık asker ile giderdün. Şimdi ne aceb sefer itdün ki yalınuz gitdün didi. Ve ba'dehû imdi işbu âlemün evvel ululığına nazâr eyle ve göklerün hareketine ve ihtilâfına nazâr eyle. Kimi nûrdan ve kimi yâkutdan kimi dahi incûden kimi altûndan ve kimi gümişden kimi la'lden kimi cevherdendür. Ve şemsün dördüncü gökde seyrine nazâr eyle. Ve büyüklüğü yüz altmış altı bu yircedür. Ve kamere nazâr eyle ki evvelki gökde olur, nûrın şemsden nîce kesb ider. Ve gice şemsün yirine nîce nâib olur ve nîce hilâl ve bedr olur. Ve ba'dehû Hak Teâlâ yiryüzinde bin dürlü cânavâr yaratdı. Altı yüzü denizde dört yüzü kara yirdedür. Evvel-i mahlûk yiryüzinde cemâdâtdur, andan sonra insândur. İmdi insân

[90b]

cân ile evvel mahlûkdur ve cism ile âhir mahlûkdur. İmdi evvelki gök feriştesi bakar sûretindedür, ikinci gök feriştesi kerkes sûretindedür, üçüncü gök feriştesi akreb sûretindedür, 
dördüncü gök feriştesi atlar sûretündedür, beşinci gök feriştesi hûrîler sûretindedür, altıncı gök feriştesi gılmânlar sûretindedür, yidinci gök feriştesi insân sûretindedür. Ve ba'dehû Hak Teâlâ aydur her kim dünyâyı cem‘ ider anun aklı yokdur. Ve her kim dünyâ ile ferah olur anun fehmi yokdur. Ve her kim dünyânun arzularına sa'y ider anun ma'rifeti yokdur. Peygamber ayıtdı yârın kıyâmet güninde Hak Teâlâ buyura dünyâyı getüreler kıyâmet birinde bir kara kandil gibi asa koyalar. Ol vaktden beru ki Hak Teâlâ dünyâyı yaratdı. Dahi ana rahmet nazarın eylememişdür. Hak Teâlâ dünyâya ayıtdı izzetüm hakkıçün eğer senün benüm katumda bir zerre kadar hürmetün var imişse idi kâfire bir içim su vermeyeydüm didi. Ve ba'dehû Hak Teâlâ dünyâyı ve ehl-i dünyâyı cehenneme buyura. Eyle gerekdür ki âlem-i esfel gubârından ve dünyâ sevmekden kurtulmak gerekdür. İmdi dünyâ sevmekden âhiret sevmek yiğgür. Zîrâ kişi dünyâ âhiretden mahrûm eyler. Ve ba'dehû

[91a]

bu ilm-i hakâyıkı bilmek sebeb-i terk-i lezzât-1 dünyeviyyedür. Ve temettu'âtı uhreviyyedür bunlar hâsıl olmaz illâ şol kimseye ki ma'kulâtdan ve mahsûsâtdan haberdâr ola. Ve ba'dehû hükemâ şöyle ittifâk itdiler ki ilm-i hendesede kamerün büyüklüğü yüz on sekiz bin dahi altmış altı mîldür ve kamerün istifâdesi şemsdendür. Ve kamere mensûbdur avâmü'n-nâs ve kâziblere ve gammâzlara ve hasûdlere ve her burcda iki buçuk gün durur. Ve cemî‘ gökleri seyr ider bir ayda ve ammâ iki yüzlü gözgüye benzer. Bir yüzü şemse mukâbildür. Kaçan şemse mukâbil olsa kamerün nûrı ziyâde olur. Ve ba'dehû kaçan yire mukârin olsa kamerün nûrı eksilür. Pes bedr ve hilâl işbu i'tibâr ile olur ve kamerün nûrı ziyâde olurken hayvânun eti ve derisi kavî olur ve kuşun yumurdası ak olur ve insânun oturması çok olur ve balık semüz olur ve ağaçlarun yimişi çok olur ve ekin eyü olur. Ve ayun eskisinde bunlarun aksidür ve aksi olur. Fasl: Şems

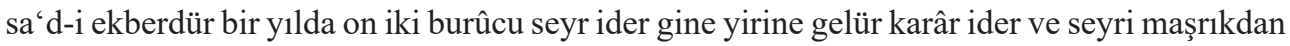
mağribedür. A‘zam-1 kevâkibdür ve nûr-1 kevkebdür. Ve Şems’ün

[91b]

misâli Pâdişâh gibidür ve yılduzları askeri gibidür ve kamer vezîr gibidür ve Utârid kâtib gibidür ve Zühre hüddâm gibidür ve Merrih sâhibu'l-ceyş gibidür ve Müşterî kâdî gibidür ve Zuhal hazâin gibidür ve eflâk ekâlim gibidür ve burclar şehirler gibidür ve derecâtlar köyler gibidür ve dakâyık mahalleler gibidür fâidesi çok olsun içün.

Fasl: Fî fadli'l-eyyâmi ${ }^{80}$ yevmü'l-cum‘a '1dü'l-mü'minîn ve yevm-i sa'ddür ve haccü'lmesâkîndür ve yevm-i vuslâtdür ve yevm-i nikâhdür. Nitekim Âdem ile Havvâ ve Belkîs ile Süleymân ve Mûsâ Safûra ile ve Muhammed-i Mustafâ Hadîce ile ve Âişe ile cumu'a gün kâbin kıldılar. Ve Âdem Peygamber cihâna cumu'a gün geldi ve uçmağa cumu'a gün girdi ve

“Günlerin fazîletleri bölümü” 
gine uçmaktan çıkd1. Cumu'a gün altı kez yüz bin kişi cehennemden azâd olur. Ve her kim cumu'a gün dırnak kese mâlı ve ömri çok ola. Ve ba'dehû Peygamber aleyhi's-selâm ayıtdı: "Bir gün Cebrâil geldi bana ayıtdı Yâ Resûlallâh! Her kim cum'a gicesi iki rek'at namâz kılsa

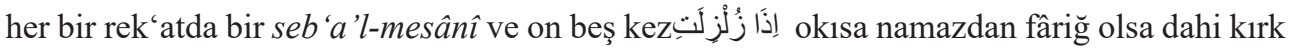
kez yâ Hayŷ̂ yâ Kayyûmu yâ Zelcelâli ve'l-ikrâm dise Muhammed-i Mustafâ'yı düşinde göre. Ve ba'dehû yevmü's-

sebt yevm-i-nahsdür, ve yevm-i mekirdür. Zîra ol gün altı kişiye mekr olund1. Biri Yûsuf aleyhi's-selâm ve biri Sâlih ve biri Nûh ve biri Îsâ ve biri Mûsâ ve biri Muhammed Mustafâ aleyhi's-selâm. Ve sebt güni nice geçerse ve gine sebt günine değin eyle geçer. Ve ba'dehû Peygamber ayıtdı şenbe gün nahsdür. Zîra ol gün ashâb-1 sebt meymûn oldılar. Peygamber aleyhi's-selâm aydur her kim şenbe gün dört rek'at namâz kılsa her bir rek'atde namâz kılsa her bir rek'atde bir Fâtiha ve üç kez dutub ve gice ihyâ itmişce sevâb vere. Ve her kim şenbe gicesi sekiz rek'at namâz kılsa her

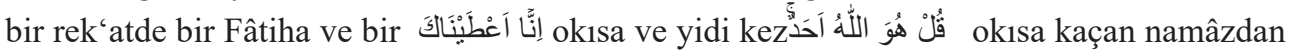
fâriğ olsa yitmiş kez istiğfâr itse Hak Teâlâ ol kişiye Kâ‘be’ye varmışca sevâb vere ve bin müsülmânı kâfirden satun almışca sevâb eline gire. Ve ba'dehû yevmü'l-ehad 'îdu'n-nasârâdur. Ve dünyâ güninün evvelidür. Ol gün imâretler başlamak ve bağlar bağçalar dikmek eyüdür. Ve ba'dehû yek-şenbe gün sa 'ddur ammâ îdu'n-nasrânîdür. Peygamber aleyhi's-selâm ayıtdı her kim yek-şenbe gün dört

rek'at namâz kılsa her bir rek'atde bir Fâtihâ okısa ve bir أمَنَ الرَّسُولن okısa cemî'-i nasrânîler sağışınca sevâb vire ve bir kez gazâ itmişce sevâb eline gire ve uçmâğun kankı kapusından gerekse uçmâğa gire didi. Bi-iznillâh dü-şenbe mübârek gündür. Hazret-i Resûl aleyhi's-selâm ol gün toğdı ve gine ol gün nakl eyledi, ve İbrâhîm Peygamber Kâ‘be’yi ol gün yapdı, ve Mûsâ Tûr Tâğına ol gün çıkdı, ve sefer itmek ol gün mübârekdür. Ve ba'dehû dü-şenbe gün ticâret günidür. Muhammed Mustafâ dü-şenbe gün cihâna geldi. Ve Cebrâîl, Peygamber'e vahy indürdi. Ve İbrâhîm Kâ‘be’yi dü-şenbede yapdı. Ve Mûsâ Tûr’a dü-şenbede çıkdı. Peygamber aleyhi's-selâm ayıtdı her kim dü-şenbe gün iki rek'at namâz kılsa her bir rek'atinde bir Fâtiha ve bir Âyetü'l-kürsî okısa ve on kez dahi إنَّاَ اعْطَيْنَاكَ okı ve on kez salavât getürse Hak Teâlâ ol kişiye cennetde bir sarây vire. Ak incûden ola ve içinde kızıl altundan kırk kürsî ola ve her kürsînün üstinde bir hûri otura didi. Ve ba'dehû se-şenbe gün kan günidür zîra ki Havvâ ol gün hayz gördi. Ve Hâbil Kâbil'i ol gün öldürdi. 
[93a]

Circîs ve Yahyâ ve Zekeriyyâ ol gün şehîd oldılar. Peygamber aydur her kim se-şenbe gün

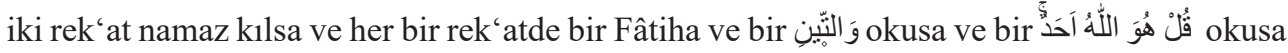
Hak Teâlâ ol kişiye yağmurlar katresince sevâblar vire. Ve ba'dehû se-şenbe gün evde oturmak eyüdür. Ammâ ol gün kan günidür. Havvâ ol gün hayz gördi ve Kâbil Hâbil'i ol gün öldürdi. Ve Circîs aleyhi's-selâm Yahyâ ilen Zekeriyyâ ol gün şehîd oldılar. Ve ba'dehû çehâr-şenbe kalîlü'l-hayrdur ammâ mübârekdür. Ve yevm-i nahsdür üç bin 'unuk ve Fir'avn ve Nemrûd ve Âd Kavmi ve Şeddâd Kavmi ve Kârûn ve Hûd Kavmi ve Sâlih ve Lût Kavmi çehâr-şenbe gün helâk oldılar. Ve âhir çihâr-şenbesi gâyet nahsdür.

Hikâyet: Ve ba'dehû Yezîd'e bir gün Bâyezîd aydur gel teferrüce gidelüm. Karındâşı aydur çehâr-şenbe günidür nahsdür. Bâyezîd aydur Yûnus bugün toğmadı mı? Karındaşı aydur bugün toğdığıçün yiri bâlık karnı olub yalıncak yatmadı mı? Bâyezîd aydur Yûsuf bugün toğmadı mı? Karındaşı aydur esîr olub zindanda yatmadı mı? Bâyezîd aydur İbrâhîm’e bugün vahy gelmedi mi? Karındaşı aydur nâr-1 Nemrûd mancılığa koyub oda

[93b]

atmadı mı? Bâyezid aydur Muhammed Mustafâ yevm-i ahzâbda nice kâfirleri helâk eylemedi mi? Karındaşı aydur ol gün nice zahmet ve sefer çekmedi mi? İmdi pes ma'lûm oldı kim nahsdür ammâ ot içmek mübârekdür. Zîrâ ki Hak Teâlâ enhârı çeşmeleri ol gün yaratdı. Ve ba'dehû ma'lûmdur ki çehâr-şenbe nahsdür. Peygamber aleyhi's-selâm ayıtdı her kim

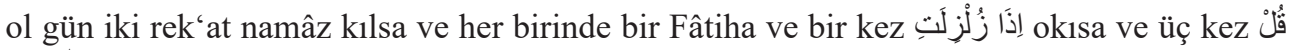
هُوَ اللُُّ آَحدّ emîn eyleye Hak Teâlâ. Yevmü'l-hamîs mübârek gündür. Hak Teâlâ nûrı ve nârı, cenneti ve cehennemi penc-şenbe gün halk eyledi. Ve günlerün fethi ol gündür. Muhammed Mustafâ aleyhi's-selâm Mekke'yi ol gün feth itdi. Ve Mûsâ Misır'a ol gün yol buldı. Ve Yûsuf ol gün Mısır'da tahta geçdi. Ve Ya'kûb Yûsuf ile ol gün bulışdılar. Ve İsmâîl ol gün dünyâya geldi. Ve ba'dehû penc-şenbe güni hâcet günidir. Peygamber ayıtdı her kim ol gün iki rek'at namâz

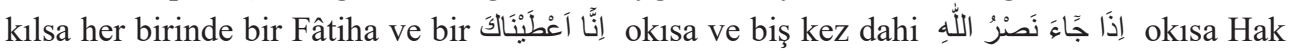
Teâlâ ol kişiye bin şehîd sevâbın vere. Ve ba'dehû çün

günleri bildük ayları dahi bilmek gerekdür ki kemâlat tahsîl ola.

İmdi bu fasıl ayları bildürür. Bir yıl üç yüz elli dört gündür. Bir yılda on bir gün naks olur, vakt olur on iki gün naks olur. İmdi bilmek gerekdür ki Muharrem yıl başıdur arab katında. Ve ammâ acem katında yıl başı nevrûzdur. Bu aya vech-i tesmiye dirler. Ve tesmiye oldur ki 
Âmir adlu bir pâdişâh varıdı. Safvân adlu bir pâdişâh ile cenk iderdi. Kaçan bu ayda buluşsa Âmir sırdı ayruk ayda buluşsa Safvân sırdı. Pes bu ay içinde cenk itmek harâm oldı. Eyle olsa bu aya muharrem diyü âd kodılar. Pes bu ayun yedinci güninde Yûnus Peygamber'i balıkdan kurtaruben çıkardı. Ve ba'dehû Hak Teâlâ arşı ve kürsi ve firdevsi ve Mîkâîl'i ve İsrâfîl'i ve Cebrâîl'i yidinci güninde yaratdı. Ve Âdem atamuz yidinci güninde tevbe eyledi. Ve Nûh seksen kişi ile Cûdî Dâğına yidinci güninde karar eyledi. Ve İdrîs yidinci güninde göğe ağdı. Ve Lût Kavmi yidinci gün helâk oldı. Ve İbrâhîm yidinci gün toğdı. Ve od İbrâhîm'e yedinci güninde gülistân oldı. Ve Mûsâ Fir‘avn'1 yidinci güninde gark eyledi. Ve Kârûn'1 yir yidinci

güninde yutdı. Ve Yûsuf zindândan yidinci güninde çıkdı. Ve Ya'kûb’un gözleri yidinci güninde açıldı. Ve ba'dehû Dâvûd ve Yahyâ ve Zekeriyyâ ve Sâlih yidinci güninde cihâna geldiler. Ve Süleymân yidinci güninde tahta ağdı. Ve Eyyûb yidinci güninde zahmetlerden kurtuldı. Ve Hüseyn yidinci güninde şehîd oldılar. Ve Îsâ Meryem'den yidinci güninde toğdı ve yidinci güninde göğe ağdı ve kavmi dahi yidinci güninde hınzîr oldılar. Ve Nemrûd yidinci gün helâk oldı. Ve ba'dehû on altıncı güninde beytü'l-makdis kıble oldı. Ve on yidinci güninde ashâb-1 fîl, ebâbîl kuş ile helâk oldı. Safer ve Receb tesmiye oldur ki bir kavm vâr idi bu ayı mübârek görmişlerdi ve bu ayda mübârek görmişlerdi seferi. Ve bu ayda cenge giderlerdi anunçün safer dirlerdi. Ki evvel güninde kâfirler Hazret-i Hüseyn'ün bâşını kesüb aldılar Dımışk şehrine girdiler. Yirminci güninde ol baş girü Hüseyn ile buluşdı. Rebîü'l-evvel'de pes bu ismi ana anunçün dirler ki ol kavm ol günde rebî‘ olıcak sefere çıkdılar. Çiçekler açılmış, çemenler bitmiş, gonca zuhûra gelmiş, gülzâr dahi açılmış sûret bulmış, otlar mevc urub rûzigâr

[95a]

bezenmiş. İmdi bu ayun adını Rebiü'l-evvel kodılar. Pes Muhammed Mustafâ aleyhi's-selâm bu ayun sekizinci güninde Medîne’yi makâm idindi. Onuncı gün Hadîce’yi helâl idindi. On ikinci güninde kendü vücûda geldi. On üçüncü gün vefât eyledi. Ve ba'dehû Rebiü'l-âhir'un evvel güninde Yûsuf bin Haccâc Kâ‘be’yi temâm itdi. On dördünci gün namâz farz oldı. Vech-i tesmiye oldur ki Mûsâ'nun kavmi Mısır'dan kaçdılar kırk gün Tîh yazusında hayrân olub turdılar. Kankı aydandur diyü târih yazdılar, son yaz ayında idi. Pes Rebiü'l-âhir diyü ad kodılar. Ve ba'dehû Cemâziye'l-ûlâ ve vech-i tesmiye bu aya budur ki zamân-1 evvelde bir Pâdişâh vâr idi âdı Melikşâh idi. Ve bir pâdişâh dahi var idi adı Güzâr idi. Ve ba'dehû Melikşâh, Güzâr'1 sıdı. Hattâ bir yüce yire kondılar, gâyet sovuk idi. Sovuk gördükleri yoğ idi, taaccüb eylediler. Ol ayun adını cemâziye'l-ûlâ diyü ad kodılar. Evvel adı Sanîn idi. Sekizinci güninde Alî cihâna geldi ve on beşinci güninde Alî dünyâdan gitdi bir kızıl deve geldi Alî hazretini götürdi, aldı gitdi. Allâh bilür ki 
[95b]

kande aldı gitdi. Ve ba'dehû Cemâziye'l-âhir ol kavm ki Melikşâh idi. Bir ayda anda turdılar yini ay toğdı gine sovuk oldı pes Cemâziye'l-âhir diyü âd kodılar. Evvel güninde Cebrâîl, Peygamber'e geldüği gündür. Ve bu ayun tokuzuncı güninde Ca'fer-i Sâdık cihâna geldi. Yigirminci gün Fâtıma Hâtûn cihâna geldi imdi Receb dimek olur. Receb'ün evvel güninde Nûh gemi yapdi. Yedinci güninde Muhammed Mustafâ mi'râc eyledi. Yigirmi sekizinci güninde Hazret-i Risâlet'e peygamberlik geldi. Ve ba 'dehû Şa ‘bânda Mûsâ Peygamber aleyhi’s-selâm ol vakt ki Tîh yazusında menn ve's-selvâ yidiler idi. Kırk yıl ol yirde oldılar. Ol kavm ki Mûsâ'dan ayru düşdiler idi. Yûşa ‘'a uydılar. Ahbâb ile ferah ve sürûr hâsıl oldı. Çoklık taaşşüb eylediler. Pes bu ayun adını Şa ‘bân kodılar. Üçünci güninde Hüseyn anadan toğdı ve dördünci güninde Hasan anadan toğdı. Ve on beşinci gün Berâ'at namâzı vâk1' oldı. On altıncı güninde halk Kâ‘be’ye döndiler, evvel zamânda Kuds’e teveccüh iderlerdi. Ve ba‘dehû Ramazân vech-i tesmiye oldur ki Ben-i Cürhâm Mekke'ye geldi, gâyet

[96a]

Zâlim kişi idi. Ve ba‘dehû İsmâîl Peygamber aleyhi’s-selâm Mekke’ye geldi. Ol günlerde gâyet 1ssı oldı, ayaklarınun derisi ısıdan döküldi hattâ katı zaîf oldılar. Ol sebebden bu aya Ramazân didiler. Üçünci güninde İbrâhîm suhuf okudı. Dördünci güninde Cebrâîl Muhammed Mustafâ'ya Kur'ân getürdü. Yidinci güninde Mûsâ'ya Tevrât indürdi. On sekizinci güninde Îsâ'ya İncîl indürdi. Yigirmi yidinci güninde Bedir Gazâsı oldı. Ve ba'dehû Ca'fer-i Sâdık ayıtdı oruç ne gündendür bilmeseler, evvel geçen orucun beşinci güni bu ayun evvelidür didi. Ve ba'dehû Şevvâl Benî Ayz, Haysemi sıyub harâç aldı, döndü yolda gelürken develer cimâ' itdiler ve oynadılar, bunlar gördükleri yoğ idi aceblediler, şâz oldılar, ya 'nî ferah düşdiler. O1 sebebden bu ayun âdını Şevvâl kodılar. Evvel güni yevm-i 'îddür. Yidinci güninde Hamzâ’yı şehîd itdiler. Ve ba'dehû Zi'l-ka'de vech-i tesmiye oldur ki Kurâz adlu bir ulu pâdişâh vâr idi Arab'da olur idi. Her dem işi cenk ve savâş iderdi. Velîkin bu ayda otururdı savaş kılmazdı. Pes bu ayun adinı

[96b]

Zi'l-ka'de kodılar. Evvel güninde Mûsâ aleyhi’s-selâm Hak Teâlâ ile va'de eyledi kim otuz gün oruç duta. Lîkin Hak Teâlâ kırk gün buyurdı dördünci güninde Ashâb-1 Kehf mağaraya girdiler. Beşinci güninde İbrâhîm Peygamber aleyhi’s-selâm Kâ‘be’yi bünyâd eyledi. Yidinci güninde Mûsâ Peygamber Fir'avn'dan kaçd1, Nîl’i geçdiler, Fir'avn leşkeri ile geçmediler, Nîl'de helâk oldılar. Ve ba'dehû Zi'l-hıcce vech-i tesmiye oldur ki Mûsâ Peygamber Tûr Dâğı'ndan indi Kudüs'e geldi, Kudüs'ü tavâf eylediler ve hac eyledi. Pes bu ayun adını Zi'l- 
hıcce kodılar. Onuncı güninde bayram old1. Ve ba'dehû bayrâm cum'aya gelse hacc-1 ekberdür. İmdi ey tâlib-i esrâr-1 İlâhi! Bilmek gerekdür ki وَيَفْعلُ اللَّهُ مَا يَثَّاءُ وَ يَحْكُُْ مَا يُرِيدُ Hak Teâlâ ne dilerse işler ve nice dilerse kılur hüküm eyler. Kimse mu'ârız olmaz. Eğer bir kişinün ömri Nûh ömrinden artuk olsa cemî‘-i ömrden artuk olsa cemî‘-i ömrini Hak Teâlâ'nun masnû‘âtınun fikrinde geçürse henüz kudret denizinden bir katre yazmaya. İmdi ben bî-çâre Bîcân sakalı ak yüzi kara hakîr günleri ve ayları anunçün

mukaddem yazdum ki tâ anlaması âsân olsun içün. Ve ba'dehû nitekim Hak Teâlâ Yâsîn

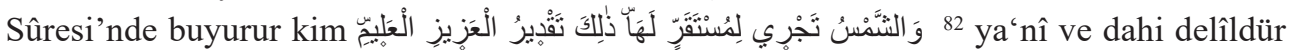

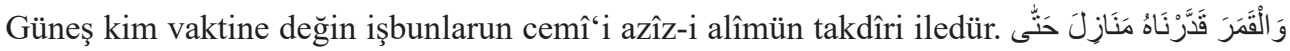

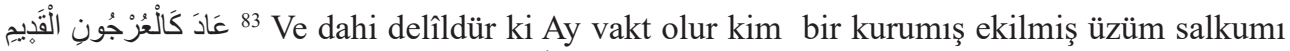

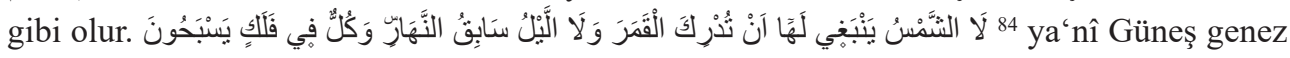
değüldir ki Ay'a yite ve ne dahi Güneş uğurdur giceden. Ve her birisi bu yılduzlarun her biri

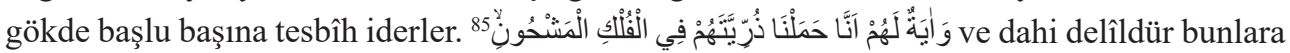

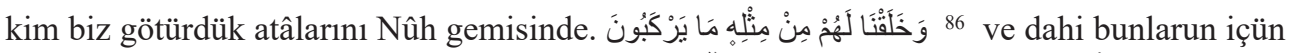

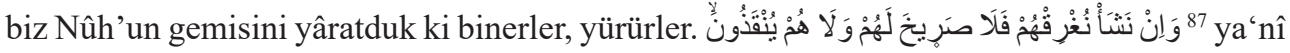
Hak Teâlâ aydur eğer biz dilesüz gemi ve âdemlerini gark iderdük, denizde hiç kimse ana meded eylemezlerdi. إلَّ رَحْمَاً

[97b]

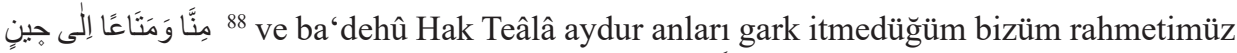

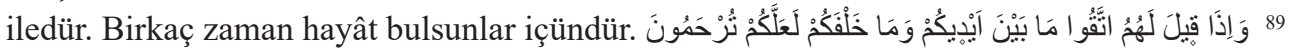
ya ‘nî kaçan eydinilse bunlara kim sakının. Sizlerden önden geçen azâblardan ki size dahi ol azâb

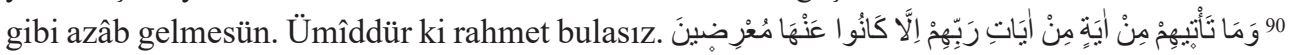
ya ‘nî bunlara dahi delîl gelmez Tanrı Teâlâ'nun delîllerinden illâ bunlar ol delîllerden hîç birisini

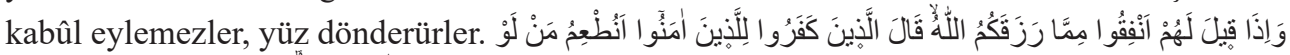

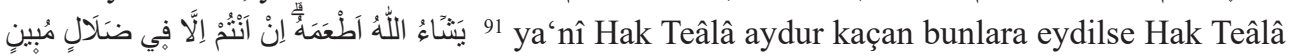

81 "Allah dilediği şeyi yapar ve istediği şeye hükm eder."

82 Yâsîn 36/38.

83 Yâsîn 36/39.

84 Yâsîn 36/40.

85 Yâsîn 36/41.

86 Yâsîn 36/42.

87 Yâsîn 36/43.

88 Yâsîn 36/44.

89 Yâsîn 36/45.

90 Yâsîn 36/46.

91 Yâsîn 36/47. 
içün sadaka verün, şol nesnelerden ki Hak Teâlâ sizlere verdi. kâfirler ayıtdılar mü'mînlere, yiyesi verelüm şol kimseye ki eğer Hak Teâlâ dilese idi ol kişiye rızk veresiyidi. Andan sonra mü'mînler kâfirlere ayıtdılar değülsiz sizler illâ ki azgunlık içindesiz didiler. وَيقُقُلُونَ مَنْى

[98a]

هَ 92 ve dahi kâfirler aydurlar yâ Muhammed bu va'de itdüğünüz kaçan

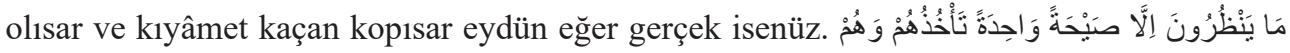

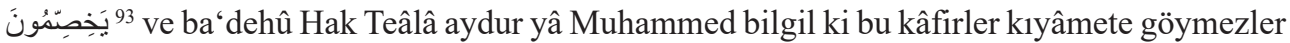
illâ İsrâfîl'in ansuzda bir çağırmağına göyerler. Ve ba'dehû ol çağırmak bunları duta. 94 ya'nî güçleri yitmeye biribirine vasiyyet eylemeye ve ne kavümlerine dönüb gelibileler. بَلَ 95 Hak Teâlâ İsrâfîl'e buyurdı Hak Teâlâ'nun buyruğın levh-i mahfûza ol indürür. İsrâfîl'ün dört kanadı vardur. Başı arşdan yukârıdur ve ayakları yidi kat yirden aşağadur. Levh-i mahfûz ki cevher-i nûrânîdür anun önündedür ve nakildür Kûtü'l-Kulûb' de ${ }^{96}$ Azrâîl ile İsrâfîl birbiri ile söyleşdiler. Azrâîl ayıtdı ben dirîleri öldüriciyin, İsrâfîl ayıtdı ben ölüleri dirildiciyin. Hak Teâlâ'dan hitâb geldi kim bunlara, siz işinüz üzerine olun ol iş size musahhar eyledüm. Ammâ hakîkatde öldürüci

[98b]

ve dirildici benven didi. Ve ba'dehû sûr bir kez çalına, bunlar sinlerinden Tanrı'dan yana

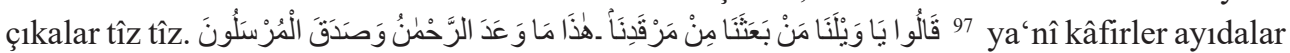
ey ve ay bize miskînlere bizi kabirden yatacağumuz yirden çıkarduğuz âh ve ay ideler. Anunçün ayıtdılar ki evvel sûr urulıcak olalar, ikinci sûr uruluncaya dek yatalar. Hîç azâb görmeyeler, temâm uyur gibi olalar. Bunlar aydalar bu oldur ki Hak Teâlâ bize va'de eyledi idi. Uşde ol va'de ki peygamber eylediyidi girçek aydurlar imiş diyeler

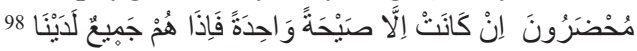

ve ba'dehû Hak Teâlâ aydur olmadı bunlarun kopmasına ve dirilmesine hemân bir kez

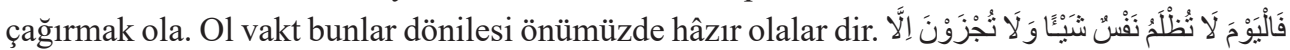

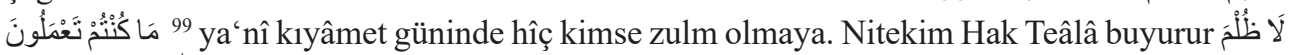

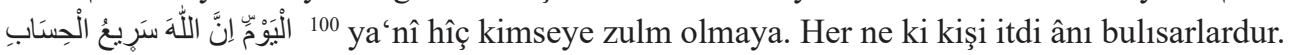
Ve ba'dehû Hak Teâlâ bu halkı bir sâatun içinde hisâb eyleye.

92 Yâsîn 36/48.

93 Yâsîn 36/49.

94 Yâsîn 36/50.

95 Yâsîn 36/51.

96 Ebû Tâlib el-Mekkî'nin (ö. 386/996) tasavvufa dair eseri.

97 Yâsîn 36/52.

98 Yâsîn 36/53.

99 Yâsîn 36/54.

100 Mü'min 40/17. 
[99a]

Ve ba'zılar aydurlar dahi tîz hisâb olına. Her kişi kim hisâb olınur şöyle sana kim hemîn kendüye hisâb olundı ve Hak Teâlâ ayda yâ Muhammed sen ümmetünle hisâb olunma ben anları hisâbdan kurtarayın didi. Peygamber aleyhi's-selâm ayıtdı yâ Rabbî ümmetümün hisâbını benüm elümde kıl. Anlarun yaramaz amellerini benden gayrı kimse mutalli‘ olmasun diye Hak Teâlâ ayda yâ Muhammed sen dilersin ki ümmetünün hisâbın senden gayrı kimse bilmeye ve ben dilerin ki ümmetünün hisâbın sen dahi bilmeyesin. Ben afv eyleyüb setr idem. 101 be-dürüstî uçmak ehli ol gün mahbûb kızlar ile meşgûl olalar. Bikrler ile zevk ideler. Dâim tena “umlar içinde olalar. Hûrîler ile gökler altında tahtlar üstinde oturub şâdîlik içinde olalar. 102 ya'nî mü'minler uçmak içinde dürlü dürlü yimişler yiyeler, her ne kim arzu iderlerse bunlara hâsıl oladır cennetde. Ve ba'dehû uçmağun aslı sudandur ammâ

[99b]

dürlü dürlü sûretde izhâr olınur, incüden ve yâkutdan ve altundan ve gümişden ve anberden ve müşkdendür. Nitekim Âdem'i toprakdan ve sudan yaratdı. İmdi bir kişinün eğer nûr-1 rûhânîsi gâlib olacak olursa tabîatınun nârı üzerine ol saîddür. Eğer tabîatınun nârı gâlib olacak olursa

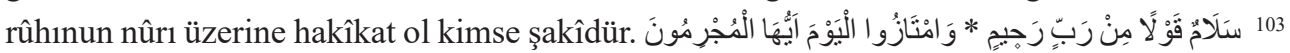
ya'nî bunlara ki mü'minlerdür dahi selâm olsun size Rabb-i Rahîm'den diye ve gine aydur iy

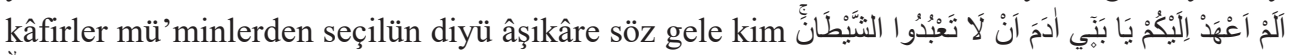

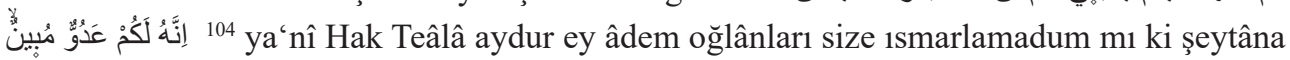
tapman ki size âşikâre düşmendür. تَّنَ 105 ve dahi size 1smarlamadum mı ki bana tapun ki bana tapmak bir yoldur ki hattâ dosdoğrı yoldur. Ve ba'dehû Yahyâ bin Muâz aydur bana bir vakt ibâdet fevt eylemen küçürekdir mevt hâlinden zîrâ ki ibâdet fevt eylemek Hak' dan kesilmekdür ve ölmek halkdan kesilmekdür. İmdi halkdan kesilmek Hak' dan

$[100 \mathrm{a}]$

kesilmek ulu azîm musîbetdür. 106 ve ba،dehû Hak Teâlâ aydur ya'nî dahi şeytân şüphesüz ve şeksüz sizden öğden nice halâyık azdurdı. Siz

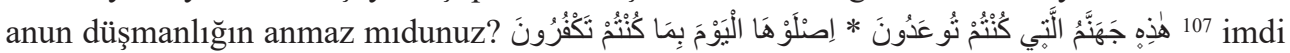

101 Yâsîn 36/55-56.

102 Yâsîn 36/57.

103 Yâsîn 36/58-59.

104 Yâsîn 36/60.

105 Yâsîn 36/61.

106 Yâsîn 36/62.

107 Yâsîn 36/63-64. 
uşde bu ol zâlimdür ki siz va'delendünüz girmeğe imdi girün odlara giyünün, bu tamuya

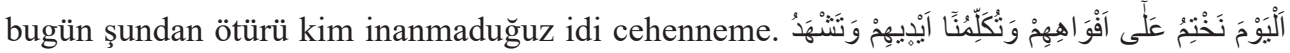

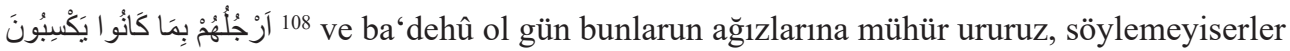
bize. Ve dahi elleri ve ayakları söyleyiserler tanukluk veriserler şuna ki bunlar anı işledilerdi anlardan tanukluk vereler. 109 ve ba dehô eger dileseydük çıkarayduk bunlarun gözlerin yol vermeğe ki velîkin sırât-1 müstakîmdür yolların

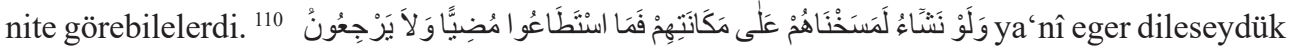
bunlarun sûretlerini bozayduk evlerinde yaturken güçleri yitmeyeydi kendüleri

[100b]

kurtarmağa. Eger dileseydük bunlara dünyâdayiken işbu azâbları anlara eyleyeydük. Ne gitmek olaydı ve ne gelmek olaydı illâ anlara mühlet verürüz yârın kıyâmetde cehenneme

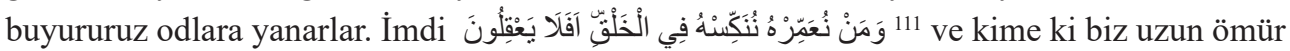
virürüz sonra kuvvetlerun giderüb zâ̂flik getürürüz ve aklın giderüb zâyil eylerüz. وَمَا عَلَّمْنَاهُ

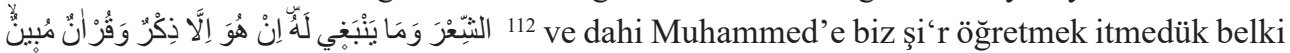
Kur'ân öğretdük ki hakkı bâtılı ol Kur'ân bildürür. Ya'nî kâfirler aydurlar Muhammed şâirdür dirler. Tanrı Teâlâ aydur ki biz Muhammed'e şi‘r öğretmedük belki Kur’ân öğretdük dimek olur.

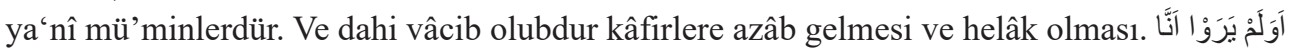
114 ya'nî Hak Teâlâ aydur görmezler mi bu kâfirler biz yâradub tururuz bunlarunçün ki biz kudretümüz ile işledük. Hayvânlar yâratduk

[101a]

bunlar ol hayvânlara hâkimlerdür. وَهُ 115 ve genez eyledük

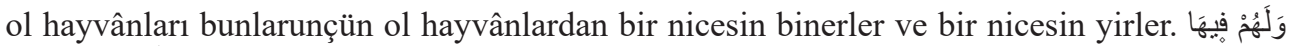

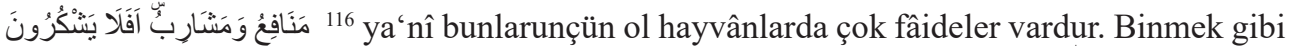
vو وَاتََََُْو امِنْ دُونِ اللَّهِ

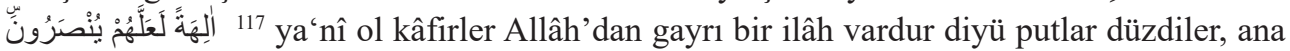

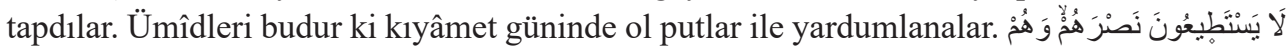

108 Yâsîn 36/65.

109 Yâsîn 36/66.

110 Yâsîn 36/67.

111 Yâsîn 36/68.

112 Yâsîn 36/69.

113 Yâsîn 36/70.

114 Yâsîn 36/71.

115 Yâsîn 36/72.

116 Yâsîn 36/73.

117 Yâsîn 36/74. 


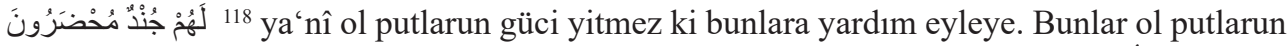

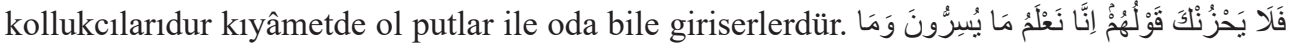
يُعْنِنْنَ 119 ya'ni Hak Teâlâ aydur yâ Muhammed seni bunlarun sözleri gussaya koymasunlar. Biz bilirüz gönüllerinde ne vâr ise. 120 ve ba dehû ya'nî insân didüği bir kâfir bir çürümiş sünüği eline aldı

[101b]

ve dutdı. Ayıtdı kim işbu çürümiş sünük gine mi dirilürimiş didi. Andan sonra bu âyet geldi. İmdi görmez mi bu kâfirler âdemi ki biz yaratmışuz anı iki pâre katre murdâr sudan. Bu

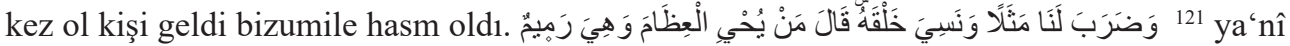
bize mesel urdı kendü yaradılduğını unutdı kim diri eyleyübdür bu sünükleri uşde çüriyüb

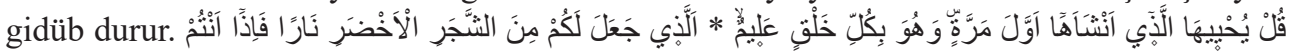
122 ya'nî ayı1t yâ Muhammed ol sünükleri Tanrı dirildür kim anı yokdan var eyledi bir kez. İmdi ol Tanrı dükeli halkı bilür ol Tanrıdur ki yaratdı sizünçün şol ağacdan kim yeşil ve kızıl odı siz ol ağacdan yandurursız ve bu dahi delîldür kudretine ki halkı gine yarada anunçün ki Hak Teâlâ suyile odı ve ağacı bir yire cem'eyledi ki sovudı söyündürmez. Ve od ağacı yakmaz. Anunçündür ki her ağacun odı vardur üzümden gayrında, üzümde od yokdur.

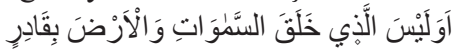

[102a]

123 ve ba، dehû bilmek gerekdür ki kürsî bir latîf cevherdendür. Yidi kat yirler ve gökler kürsî kâtında bir sahrâda bir halka gibidür. Ve kürsî dahi arş kâtında bir sahrâda bir halka gibidür arşda âsılub durur bir kandîl gibi. Ve ba'dehû Ebu'l-Leys aydur Hak Teâlâ evvel yiryüzünü yaratdı bir kızıl aya taşı kadar Ka'be yirinde. Andan sonra gökleri yaratdı yirün üzerine döşedi. Evvelki gök yeşil zeberceddür, ikinci gök saru yâkûtdandur, üçünci gök k1zıl yâkûtdandur, dördünci gök ak gümişdendür, beşinci gök kızıl altundandur, altıncı gök ak incüdendür, yidinci gök nûrdandur. Ve her gök biş yüzyıllık kalınlığı vardur araları dahi eyledür. Alt1 ve üsti dopdolu müsebbihlerdür ve mukaddislerdür. Ve ba'dehû değil midür ol Tanrı kim gökleri ve yirleri yaratdı güci yitmez mi kim bir bunlarun gibi gine yarada. Kâdirdür ve hem

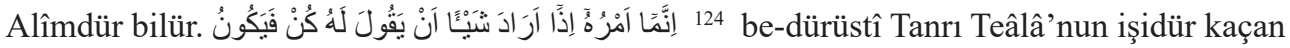
kim dilese bir nesneyi yarada, Hak Teâlâ ol nesneye ayda "Olgil” diye fî̀'l-hâl olur ol nesne.

[102b]

118 Yâsîn 36/75

119 Yâsîn 36/76.

120 Yâsîn 36/77.

121 Yâsîn 36/78.

122 Yâsîn 36/79-80.

123 Yâsîn 36/81.

124 Yâsîn 36/82. 


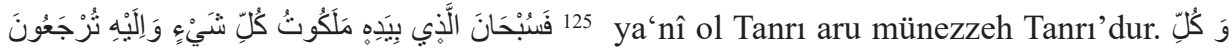

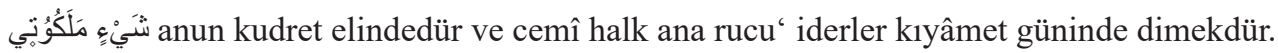

125 Yâsîn 36/83. 


\section{EK-3: Ahmed-i Bîcân'ın Müntehâ II Adlı Eserinde Mevcut Bir Harita ${ }^{126}$}

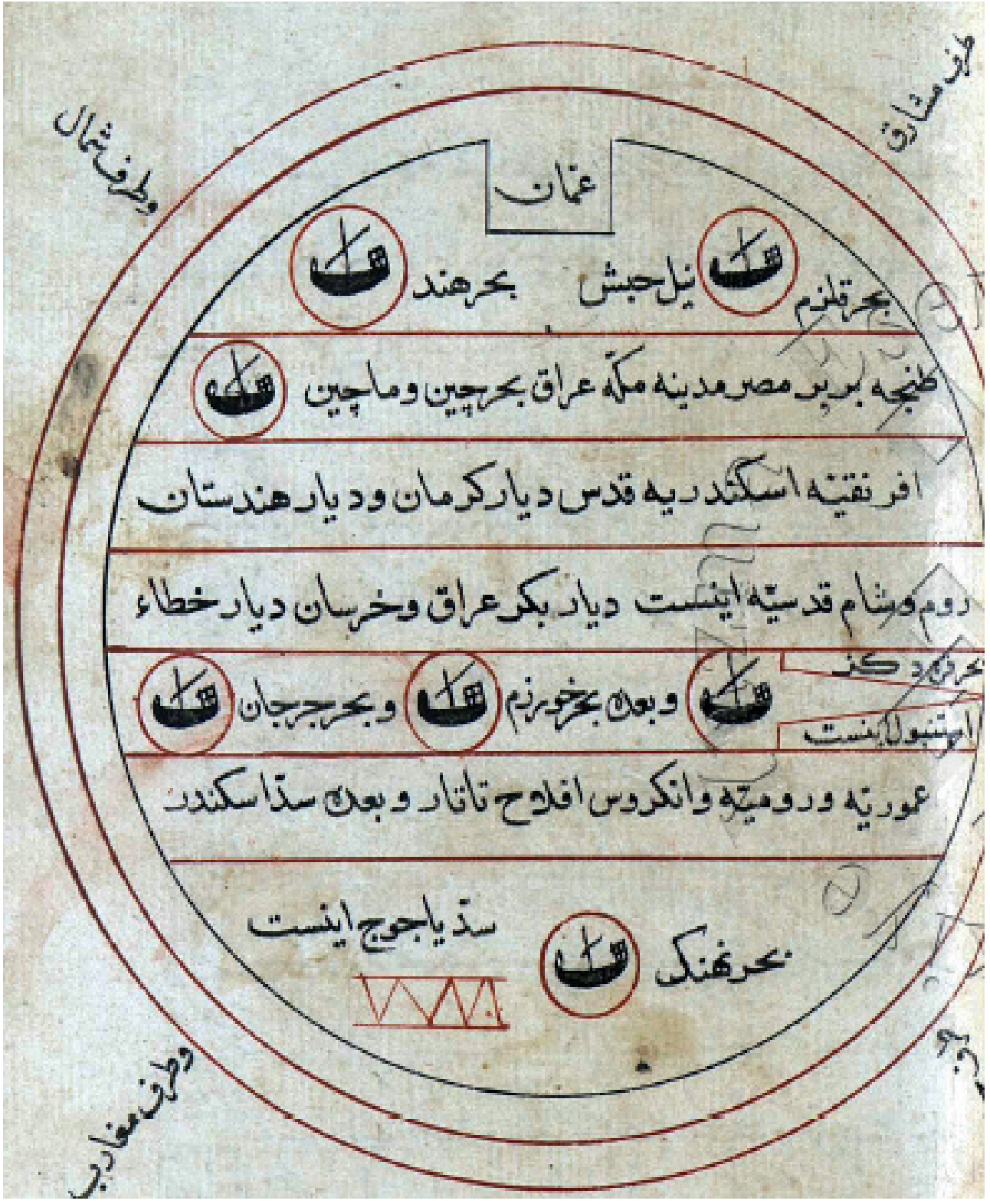

126 Ahmed-i Bîcân, Müntehâ II (İstanbul: Süleymaniye Kütüphanesi, Yazma Bağışlar, 7585), 86b. 
Hakem Değerlendirmesi: Dış bağımsız.

Çıkar Çatışması: Yazarlar çıkar çatışması bildirmemiştir.

Finansal Destek: Yazarlar bu çalışma için finansal destek almadığını beyan etmiştir.

Peer-review: Externally peer-reviewed.

Conflict of Interest: The authors have no conflict of interest to declare.

Grant Support: The authors declared that this study has received no financial support.

\section{Kaynakça/References}

Ahmed Cevdet Paşa. Belâgat-ı Osmâniyye. nşr. Turgut Karabey- Mehmet Atalay. Ankara: Akçağ Yayınları, 2017.

Bâdî, Ahmed Efendi. Riyâz-ı Belde-i Edirne- 20. Yüzyıla Kadar Osmanlı Edirne’si. nşr. Niyazi Adı̈üzel - Raşit Gündoğdu. Edirne: Trakya Üniversitesi Yayınları, 1435 /2014

Beyazıt, Ayşe. Müntehâ - Fusûsu'l-hikem üzerine bir çalışma. İstanbul: İnsan Yayınları, 2011.

Bursalı Mehmed Tâhir. Osmanlı Müellifleri. İstanbul: Matbaa-i Âmire, 1333.

Çelebioğlu, Âmil. “Ahmed-i Bîcân”. Türkiye Diyanet Vakfi İslam Ansiklopedisi. 2/50. İstanbul: TDV Yayınları, 1989.

Çelebioğlu Âmil vd. "Yazıcı-oğlu". İslam Ansiklopedisi. 13/366. İstanbul: MEB Yayınları, 1986.

Dönmez, Hanife. Muhammediye'de İnsan-ı Kamil Düşüncesi. İstanbul: İstanbul Üniversitesi, Sosyal Bilimler Enstitüsü, Doktora Tezi, 2018.

Ergiri, Münüre Beyhan. Muhammediye ve Envârü'l-Âşıkîn'de Hz. Ali. İstanbul: Üsküdar Üniversitesi, Tasavvuf Araştırmaları Enstitüsü, Yüksek Lisans Tezi, 2020.

Gelibolulu Mustafa Âli. Künhü'l-Ahbâr. nşr. Ali Çavuşoğlu. Ankara: Türk Tarih Kurumu, 1440/2019.

Gönül, Behced. “Yazıcı Selahattin ve Oğulları: Hayatları ve Eserleri”, İstanbul Üniversitesi, Edebiyat Fakültesi Lisans Tezi, 1938/1939 Dönemi.

Kâtib Çelebi. Keş̧ǚz-zünûn. nşr. Şerefettin Yaltkaya - Kilisli Rifat Bilge. Ankara: Türk Tarih Kurumu, 1435/ 2014.

K1lıç, Mahmud Erol. "Fusûsu'l-Hikem”. Türkiye Diyanet Vakfi İslam Ansiklopedisi. 13/232.

Maden, Şükrü. “Osmanlılar'da Yâsîn Sûresi Tefsir Geleneği ve Ebû İshâkzâde Mehmed Es'ad Efendi'nin Yâsîn Sûresi Tefsiri”. Osmanlı Döneminde Tefsir. haz. Hidayet Aydar vd. İstanbul: Ensar Neşriyat, 2018.

Müstakîmzâde, Süleymân Sâdeddîn. Tuhfe-i Hattatin. nşr. İbnülemin Mahmud Kemal. Ankara: Türk Tarih Encümeni, 1346/1928.

Özcan, Mehmet Fatih. Envârü̉'l-Âşıkin ve Muhammediye'de Manevi Eğitim. Konya: Necmettin Erbakan Üniversitesi, Eğitim Bilimleri Enstitüsü, Yüksek Lisans Tezi, 2019.

Tâhirü'l-Mevlevî. Edebiyat Lügatı. nşr. Mustafa Kirenci. İstanbul: Büyüyenay Yayınları, 2019.

Taşköprîzâde, Ahmed Efendi. eş-Şekâi 'ku'n-Nu 'mâniyye fî Ulemâi-d-Devleti 'IOsmâniyye-Osmanlı Alimleri. İstanbul: Türkiye Yazma Eserler Kurumu, 1440/ 2019.

Uğur, Abdullah. Yazıcıoğlu Ahmed Bîcân Efendi ve Envâru'l-Âşılkîn Adlı Eseri (İnceleme-Metin). İstanbul: Marmara Üniversitesi, Türkiyat Araştırmaları Enstitüsü, Doktora Tezi, 2019.

Uludağ, Süleyman. “Cendi”. Türkiye Diyanet Vakfi İslam Ansiklopedisi. 7/361. İstanbul: TDV Yayınları, 1993. 
Vassâf, Osmanzâde Hüseyin. Sefine-i Evliyâ. nşr. Mehmet Akkuş - Ali Yılmaz. İstanbul: Kitabevi, 1432/2011. Yamak, Mehmet Bilal. Yazıcızâde Kardeşlerin Tasavvufĩ Görüşleri ve Osmanlı'ya Tesirleri. İstanbul: İstanbul Üniversitesi, Sosyal Bilimler Enstitüsü, Doktora Tezi, 2021.

Yazıcızâde, Ahmed-i Bîcân. Müntehâ II. İstanbul: Süleymaniye Kütüphanesi, Yazma Bağışlar, 7585, 81a-102b. Yazıcızâde, Ahmed-i Bîcân. Müntehâ II. Ankara: Milli Kütüphane, 06 Mil Yz A 3271.

Yazıcızâde, Muhammed Efendi. el-Münteha. İstanbul: Süleymaniye Kütüphanesi, Pertev Paşa, 293.

Yazıcızâde Muhammed Efendi. Şerhu Fusûsu'l-Hikem (Müntehâ). nşr. İbrâhim el-Keyyâlî. Beyrut: Kitâb Nâşirûn, 2013.

Yazıcıŏlu, Mehmed. Muhammediyye. nşr. Âmil Çelebioğlu. İstanbul: Dergâh Yayınları, 1439/2018. 